Exploring differences in financial literacy across countries: the role of individual characteristics and institutions 
The Working Paper series of the Oesterreichische Nationalbank is designed to disseminate and to provide a platform for discussion of either work of the staff of the OeNB economists or outside contributors on topics which are of special interest to the OeNB. To ensure the high quality of their content, the contributions are subjected to an international refereeing process. The opinions are strictly those of the authors and do in no way commit the OeNB.

The Working Papers are also available on our website (http://www.oenb.at) and they are indexed in RePEc (http://repec.org/).

Publisher and editor

Editorial Board

of the Working Papers

Coordinating editor

Design

DVR 0031577

ISSN 2310-5321 (Print)

ISSN 2310-533X (Online)

(C) Oesterreichische Nationalbank, 2018. All rights reserved.

Oesterreichische Nationalbank

Otto-Wagner-Platz 3, 1090 Vienna, Austria

PO Box 61, 1011 Vienna, Austria

www.oenb.at

oenb.info@oenb.at

Phone (+43-1) 40420-6666

Fax (+43-1) 40420-046698

Doris Ritzberger-Grünwald, Ernest Gnan, Martin Summer

Martin Summer

Communications and Publications Division 


\title{
EXPLORING DIFFERENCES IN FINANCIAL LITERACY ACROSS COUNTRIES: THE ROLE OF INDIVIDUAL CHARACTERISTICS AND INSTITUTIONS*
}

\author{
Andrej Cupak $\nmid$ Pirmin Fessler $\ddagger$ Maria Silgoner $\$$ Elisabeth Ulbrich $\mathbb{I}^{\ddagger}$
}

February 2018

\begin{abstract}
We examine recently compiled microdata from the OECD/INFE survey covering information on the financial literacy of adult individuals from twelve countries around the globe. We find large differences in financial literacy across countries and decompose them into those explainable by differences in individual characteristics and those that cannot be explained by such differences. We show that individual characteristics matter with regard to differences in average financial literacy, but do not fully explain the observed differences. We further relate the unexplained differences in our microeconometric analysis to institutional differences across countries. We find strong relationships between the differences in financial literacy not explained by individual characteristics and life expectancy, social contribution rate, PISA math scores, internet usage, and to a lesser degree by GDP per capita, the gross enrolment ratio and stock market capitalization. Our results suggest that there is room for harmonization of economic environments across countries regarding decreasing inequality in the population's financial literacy.
\end{abstract}

JEL Classifications: D14, D91, I20

Key Words: financial literacy gaps, inequality, decomposition analysis, counterfactual methods, personal finance, survey data

${ }^{*}$ We are grateful to the OECD/INFE working group for granting access to the individual-level data. We would like to thank Alyssa Schneebaum and an anonymous referee for helpful comments and suggestions. We are also grateful to audiences at the following seminars and conferences: Oesterreichische Nationalbank research seminar (Vienna, 2017); National Bank of Slovakia research seminar (Bratislava, 2017); HFCS network meeting at the ECB (Frankfurt, 2017); Joint ECB and Banque de France conference on household finance and consumption (Paris, 2017); and Slovak Economic Association annual conference (Kosice, 2017). The views expressed in the paper do not necessarily reflect the views of the Oesterreichische Nationalbank, the National Bank of Slovakia, the Eurosystem, or the LIS: Cross-National Data Center in Luxembourg. Andrej Cupak was a visiting researcher at the Oesterreichische Nationalbank when he started this research project.

${ }^{\dagger}$ Research Department, National Bank of Slovakia; and LIS: Cross-National Data Center in Luxembourg, cupak@lisdatacenter.org.

${ }^{\ddagger}$ Economic Analysis and Research Department, Oesterreichische Nationalbank, pirmin.fessler@oenb.at.

${ }^{\S}$ Foreign Research Division, Oesterreichische Nationalbank, maria.silgoner@oenb.at.

IFinancial Education Unit, Oesterreichische Nationalbank, elisabeth.ulbrich@oenb.at. 


\section{Non-technical summary}

Modern life is full of financial choices. These vary from basic day-to-day decisions such as organizing budgets to more complex ones such as taking a loan, participating in private pension savings schemes, or investing in sophisticated financial instruments. Recent literature has shown that along with standard socio-economic characteristics that vary across individuals, financial literacy is a relevant ingredient for making sound financial decisions. Being financially literate is not only important for the wellbeing of consumers themselves, but also for the financial system as a whole. Consumers' informed and sound financial choices are important for financial stability. If better financial literacy also leads to more sound financial behavior, we can expect fewer financial problems and ultimately fewer shortfalls in financial payments. Generally, the risk-bearing capacity of households and the financial system as a whole would increase with greater financial literacy.

Average financial literacy differs markedly across countries. What was missing in the literature until now, though, has been an understanding of why there are these observed differences. Is financial literacy higher in one country because its population has certain characteristics (such as higher education), or is there something else at play? In this study, we estimate which differences in the gap are explainable by individual characteristics (age, education, household size, working status, and others) and which remain attributable to factors we cannot observe. Learning what is behind the gap in financial literacy across countries is important because the findings might suggest different policy conclusions. Imagine a gap in observed financial literacy between two countries. On the one hand, this gap may exist even within education groups; this would be the case if financial literacy differed among the highly educated across the two countries. On the other hand, the gap could exist across countries even if the financial literacy within education groups across countries were the same; this could be the case if the share of highly educated individuals is higher in one country. From a policy perspective, these two cases need to be dealt with differently. Whereas the first raises the question of why similarly educated groups have different financial literacy across countries, the second case can be addressed by increasing educational attainment.

Our results show that differences in individual characteristics matter considerably. We also show that different socioeconomic environments across countries might play a role in explaining varying levels of financial literacy. We conclude that individual characteristics should be taken into account when comparing financial literacy across countries, specifically when the countries are ranked based on their populations' level of financial literacy, as in the OECD/INFE (e.g. OECD, 2016) report. It is rather important to have an "apples to apples" comparison to design policies in an informed way. 


\section{Introduction}

The importance of financial literacy as a main ingredient of informed choices and sound financial behavior of consumers has recently been recognized in the literature (see e.g. Campbell, 2006; Jappelli, 2010; Hastings et al., 2013; Fernandes et al., 2014; Lusardi and Mitchell, 2014). Moreover, the literature shows that poor outcomes in household finance and questionable investment decisions mostly occur for households with low levels of income and financial literacy (Campbell, 2006; Badarinza et al., 2016).

We observe large differences in average financial literacy across countries (Lusardi and Mitchell, 2014; Standard and Poor's, 2014). The policy implications of this finding are, however, unclear since this depends on the homogeneity of the populations. It remains unknown how much of the observed difference is country-specific and how much is driven by differences in the individual characteristics of the (sampled) population. We deliver estimates of how much of this difference is due to differences in the characteristics of the population.

We seek to answer the following research questions in this paper: How large are financial literacy gaps across countries? Are the observed differences in financial literacy mainly due to differences in observable individual characteristics? Do institutional factors play a role in explaining financial literacy gaps across countries?

These fundamental questions are relevant for potential policies aimed at increasing financial awareness. To illustrate why it is important to not only use unconditional comparisons such as those presented in the existing literature on differences in financial literacy across countries (e.g. OECD, 2016), we point to an example with regard to educational attainment. On the one hand, a gap in average financial literacy may exist across countries within education groups; this would be the case if financial literacy differed among the highly educated in country A versus country B. On the other hand, a gap could exist across countries even if the financial literacy within education groups is the same across countries if the share of, say, highly educated individuals is higher in country A than in country B. From a policy perspective these gaps need to be dealt with differently. Whereas the first raises the question of why similarly educated groups have different financial literacy across countries, the second case can be addressed by increasing educational attainment.

Furthermore, we investigate whether the links between individual characteristics and financial literacy differ for individuals with low (basic) and high (advanced) levels of financial literacy. Whereas educational attainment might be key to basic financial literacy, its relevance might be less in the case of more advanced financial literacy. 
Finally, we ask which differences in institutions are correlated with cross-country differences in financial literacy that cannot be explained by individual characteristics. Characteristics might explain part of the gap, but their interplay with different environments across countries is potentially relevant when explaining financial literacy gaps. One potentially relevant institutional difference related to financial literacy may be different welfare state regimes. In some countries (such as Brazil, Russia, or the UK), investing privately for old age provision or other precautionary motives is more important than in others (such as Austria, Finland, or Germany). Moreover, the supply of financial services is different in different countries. In some countries, the intermediation of banks is stronger (such as in continental Europe) than in others (such as the UK).

In the previous literature, researchers have analyzed differences in financial literacy across countries and groups of individuals primarily in a descriptive way. For example, according to the Standard and Poor's (2014) survey, the average percentage of adults that answered three out of four financial literacy questions correctly is $56 \%$ in the old EU member states; $63 \%$ in Australia, the USA, and Canada; and $45 \%$ in the Central and Eastern European (CEE) new EU member states. Likewise, results of the OECD PISA survey show worse results for highschool students from CEE countries compared to other Western European countries (OECD, 2013). Recently, the OECD (2016) showed substantial differences in the financial literacy of the adult population across the world as well as across European countries. Other examples of descriptive studies on cross-country financial literacy gaps include Atkinson and Messy (2011) and Lusardi and Mitchell (2011). An exception is a study by Jappelli (2010), who analyzes the relationship between macroeconomic variables and economic literacy using international panel data on 44 countries over the period 1998-2008. Despite the identification of important factors driving differences in economic literacy across countries, the main shortcoming of Jappelli (2010)'s study is that the level of economic literacy of the particular country is proxied by the economic literacy of business leaders, hence offering a potentially biased picture.

Thus, until now, the differences in the observed distribution of financial literacy across households and individuals have not been studied in a cross-country framework using comparable individual-level survey data. We deliver such an analysis by answering the question of what (possibly) determines the observed differences in financial literacy of individuals between countries by employing microeconometric tools from the policy-evaluation and decomposition literature.

Our study makes several contributions to the empirical literature on financial literacy and household finances. To our knowledge, we are the first to do a detailed analysis of the newest 
wave of the OECD/INFE database on financial competencies of individuals. These data were made available for research in the summer of 2017. The advantage of this database is its broad set of questions, focusing on an extended set of financial knowledge questions as well as aspects of financial attitudes and behavior. We are also the first to employ counterfactual decomposition techniques to analyze the observed differences in financial literacy in a cross-country perspective. In our framework, we consider individuals from Finland as a benchmark (reference) for financial literacy of individuals from other countries available in our dataset (namely Austria, Brazil, Canada, Croatia, Hong Kong, Hungary, Germany, Jordan, The Netherlands, Russia, and the UK). ${ }^{1}$ Our findings help to better understand the potential determinants of gaps in financial literacy between countries, which are sometimes substantial - nearly $20 \%$ in some cases (e.g. Finland vs. Croatia or Russia). We devise a two-step empirical strategy to first decompose the differences into those due purely to different individual characteristics across countries and the remainder. Then, we use these remaining parts to analyze the potential linkage to institutions and a country's macroeconomic environment. Our methodological framework builds on the existing literature of Christelis et al. (2013) and Bover et al. (2016).

The rest of this paper is structured as follows. Section 2 introduces the data. Section 3 includes the empirical strategy. Section 4 presents empirical results. Section 5 concludes.

\section{Data}

The data used for the analysis of financial literacy gaps across countries come from the OECD/INFE (International Network for Financial Education) survey of adult financial literacy competencies. While the survey was conducted in more than 30 countries around the world, only a few countries made the data available for research purposes. Hence, we have managed to access individual-level data from Austria, Brazil, Canada, Croatia, Finland, Germany, Hong Kong, Hungary, Jordan, The Netherlands, Russia, and the UK accounting together for more than 15,000 observations. A unique feature of this survey is that the questions are asked in a harmonized way across countries, making the results comparable, a major advantage as compared to previous surveys on financial literacy. Also, the set of financial literacy questions is much broader than in previous studies. In the earlier surveys, usually three/four basic financial literacy questions on interest rates, inflation and diversification/riskiness were asked (Lusardi and Mitchell, 2014). In the OECD/INFE survey, questions include concepts such as time value of money, interest paid on loans, interest and principal, compound interest, risk

\footnotetext{
${ }^{1}$ The choice of Finland as a reference category is reasonable not only for the data availability, but also for other reasons. For example, the Finnish population (both adults and high-school students) rank among the best in different financial literacy surveys (e.g. OECD, 2013, 2016) compared to the population from other European countries. Furthermore, Finnish households show an intense interaction with financial markets, as nearly $39 \%$ of households hold risky financial assets in their portfolios (Bover et al., 2016).
} 
and return, inflation, and risk diversification. The data also contains standard socio-economic characteristics.

Table 1 shows basic information with regard to the data collection in the countries were data is already accessible. In 8 of the 12 countries face-to-face personal computer assisted interviews were conducted. In one of them (Russia) some interviews were also conducted via telephone. Two other countries used purely telephone interviews (Canada and Germany) whereas two gathered the data via online interviews (The Netherlands and the United Kingdom). The sample size ranges from 1,000 (Hong Kong and the United Kingdom) to 2,002 (Brazil). In many countries the national central banks were responsible for gathering the data and delivering it to the OECD/INFE. In others also universities, ministries or other governmental institutions also conducted the harmonized survey developed by the OECD/INFE.

[Enter Table 1 here]

For our analysis we use a set of variables which is fully harmonized in all countries shown in Table 2. It consists of our main variable of interest, the financial literacy score, which is itself calculated from the answers given to a set of seven questions examining the financial literacy of respondents. They deal with the understanding of inflation, interest, interest plus principal, compound interest, the relationship between risk and return and diversification. The detailed questions are listed in Appendix A. The financial literacy score of individuals is computed similarly to the extant literature on financial literacy (e.g. Lusardi and Mitchell, 2014). Hence, the financial literacy score (as also used by the OECD/INFE) is computed as a sum of all (seven) correctly answered questions asked in the survey.

In our empirical analysis, we first use a set of exogenous socio-economic individual characteristics as predictors for the stock of financial literacy. In Appendix B, we also include a set of endogenous variables capturing the experience of respondents with financial products and financial planning. As individual characteristics we use age category dummies, a gender dummy, a dummy for marital status, a dummy for university education and dummy variables for differences in employment status. Furthermore we use a variable on the income buffer indicating that the individual has a financial buffer of at least three times the monthly net income, which therefore is also a crude measure of financial wealth. To cover experience in Appendix B we use dummies on having a budget plan, being an active saver, holding risky assets and engaging in long-term financial planning.

[Enter Table 2 here] 
Figure 1 shows the distributions of the financial literacy score across all countries covered in our analysis. In most countries the majority of individuals are able to answer 5 or more questions correctly, in some countries the distribution is more skewed than in others.

[Enter Figure 1 here]

Table 3 shows descriptive statistics (means and standard deviations) for all countries and all variables used in our empirical analysis. Note, that while the mean financial literacy score varies substantially across countries, it still lies above 4.1 and below 5.2 (out of 7 ) correctly answered questions in all countries. Also individual characteristics $X$ vary substantially. In some countries (Brazil) less than $10 \%$ of the population have university degrees while in others (Canada, Jordan, The Netherlands and the UK) the share is above 30\%. Also the proxy for financial wealth, i.e. the income buffer variable identifying individuals with at least 3 month of their monthly income in financial assets, varies substantially. While in Russia only $24 \%$ report having such a financial buffer, $69 \%$ of Canadians do so. Also shares of singles and employment status show remarkable differences. Regarding the individual characteristics we use to capture experience in Appendix B, we find that the shares of individuals holding risky assets is rather different across countries. But also the softer measures of having a budget, being an active saver as well as financial planning reveal substantial differences which might potentially explain differences in financial literacy scores.

[Enter Table 3 here]

\section{$3 \quad$ Empirical strategy}

To study differences in financial literacy we employ different empirical tools. In this section we lay out our empirical approach. First, we present means of financial literacy across different socioeconomic groups across countries in subsection 3.1. Second, we estimate a conditional expectation function of financial literacy, controlling for country level fixed effects in subsection 3.2. Third, we decompose observed differences in financial literacy across countries and types of individuals by employing standard counterfactual decomposition techniques (Blinder, 1973; Oaxaca, 1973) in subsection 3.3. This step also includes use of the framework of unconditional quantile regressions (Firpo et al., 2007, 2009) to extend our approach beyond the mean in subsection 3.4. Finally, we correlate the unexplained parts of the gaps in financial literacy with selected aggregate macroeconomic indicators which have been shown to influence financial literacy at the country-level in subsection 3.5. The last step of our empirical framework builds on the previous studies of Jappelli (2010), Christelis et al. (2013), and Bover et al. 
(2016).

\subsection{Average financial literacy across socioeconomic characteristics and coun- tries}

Formally, we observe a cross section of draws from country distribution functions $F^{c}$ of countries $c \in C$, of the matrix $(L, X)$, where $L$ denotes financial literacy and $X$ a vector of individual characteristics such as education and age or indicators denoting experiences with financial products. Let us think of financial literacy as an outcome variable and individual characteristics as covariates. We calculate simple (conditional) means across different subgroups and countries. These descriptive results are discussed in subsection 4.1.

\subsection{Estimation of the conditional expectation function}

As a preliminary step to our empirical framework, we estimate the population conditional expectation function $(\mathrm{CEF}) \mathbb{E}(L \mid X)$. If the CEF is linear, than the population regression function is the population CEF. But even if it is not linear, the population regression function is the best linear predictor of the population CEF in a minimum mean squared error sense. Therefore we use a weighted linear regression to estimate the population CEF:

$$
L=\alpha+\beta^{\prime} X+\gamma I+\varepsilon,
$$

where $\alpha$ denotes a constant, $X$ contains the predictors, $\beta$ the slope parameters, $I$ includes country fixed effects with parameter vector $\gamma$ and $\varepsilon$ is the error term. The estimates for the predictive effects $\beta$ of different socioeconomic characteristics on financial literacy are discussed in subsection 4.2 .

\subsection{Decomposition analysis}

As we are interested in explaining the differences in observed financial literacy across countries, we decompose them by means of the Blinder-Oaxaca (B-O) framework (Blinder, 1973; Oaxaca, 1973). The B-O decomposition technique has been predominantly used in the labor economics literature to study gaps in wages and employment. Recently, this method has also been applied in the field of household finance to study differences in stock-holdings between US and euro-area households (Christelis et al., 2013), wealth differences across euro-area countries (Mathä et al., 2017), or to study financial literacy gaps between male and female populations in the US (Fonseca et al., 2012). 
In our case, the B-O decomposition defines the mean difference in financial literacy scores of individuals from the particular country studied and individuals from the reference group, Finland. The mean difference is divided into two main parts - one explained by group differences in observable individual characteristics under consideration, and another that cannot be accounted for by differences in observed individual characteristics - i.e. differences in coefficients, or how literacy is "produced" in the particular country.

Formally, we want to answer the question of how much of the mean difference in financial literacy is accounted for by differences in characteristics of individuals between a benchmark country $c=j$ (Finland) and countries $c \in C$. The mean difference can be written as

$$
\triangle \mu_{L c}=\mathbb{E}\left(L_{c=j}\right)-\mathbb{E}\left(L_{c}\right)
$$

We can rewrite this difference based on regression parameters and decompose it into a part explained by differences in characteristics $X$ and an unexplained part,

$$
\triangle \mu_{L c}=\left[\mathbb{E}\left(X_{c=j}\right)-\mathbb{E}\left(X_{c}\right)\right]^{\prime} \beta_{c=j}+\left[\mathbb{E}\left(X_{c}\right)^{\prime}\left(\beta_{c=j}-\beta_{c}\right)\right]
$$

where $\beta_{c=j}$ and $\beta_{c}$ are coefficient vectors from regressions including only individuals of the reference country $c=j$ and country $c$, respectively. The first part $\left[\mathbb{E}\left(X_{c=j}\right)-\mathbb{E}\left(X_{c}\right)\right]^{\prime} \beta_{c=j}$ is then the part of the difference that is due to differences in the individual characteristics $X$. $\triangle \hat{\mu}_{L c}$ can then be estimated as,

$$
\Delta \hat{\mu}_{L c}=\underbrace{\left(\bar{X}_{c=j}-\bar{X}_{c}\right)^{\prime} \hat{\beta}_{c=j}}_{\text {explained }}+\underbrace{\bar{X}_{c}^{\prime}\left(\hat{\beta}_{c=j}-\hat{\beta}_{c}\right)}_{\text {unexplained }},
$$

where $\bar{X}_{c=j}$ and $\bar{X}_{c}$ are covariate group means of the reference country $c=j$ and country $c$, respectively. Finally, we denote the estimate of the unexplained part for each country $c$, $\mathbb{E}\left(X_{c}\right)^{\prime}\left(\beta_{c=j}-\beta_{c}\right)$, which we use in a further step of our analysis by

$$
\chi_{c}=\bar{X}_{c}^{\prime}\left(\hat{\beta}_{c=j}-\hat{\beta}_{c}\right) .
$$

We discuss the results of our decomposition in subsection 4.3.

\subsection{Decomposition beyond the mean}

The reasons for differences in average financial literacy might be different for those in the lower or higher parts of the distribution. Whereas in the lower part it is mostly about very basic math (cognitive) skills (e.g. interest calculation), it is rather knowledge about the functioning of certain sophisticated financial products at the top of the distribution. Basic schooling might 
be important in the lower, but not important at all in the upper part. Therefore, to examine whether the result of our decomposition holds also beyond the mean, we employ recently developed tools from the microeconometric decomposition literature.

We decompose distributions in the financial literacy scores between individuals from the benchmark country $c=j$ and country $c$ by using recentered influence function (RIF) regressions along with the B-O technique (Firpo et al., 2007, 2009). ${ }^{2}$ To do so we basically replace the country level regressions underlying our approach with RIF-regressions. An RIF-regression is similar to a standard regression, except that the dependent variable is replaced by the recentered influence function of the statistic of interest (see Firpo et al., 2009).

For the readers' convenience we summarize the basic approach. For our case of quantiles of financial literacy scores $L$, the $I F\left(L, Q_{\tau}\right)$ is given as $\left(\tau-\mathbb{1}\left\{L \leq Q_{\tau}\right\} / f_{L}\left(Q_{\tau}\right)\right.$, where $\mathbb{1}\{\cdot\}$ is an indicator function, $f_{L}(\cdot)$ is the density of the marginal distribution of $L$, and $Q_{\tau}$ is the population $\tau$-quantile of the unconditional distribution of $L$. The $R I F\left(L ; Q_{\tau}\right)$ is then equal to $Q_{\tau}+I F\left(L, Q_{\tau}\right)$, and can be written as

$$
R I F\left(l ; Q_{\tau}\right)=Q_{\tau}+\frac{\tau-\mathbb{1}\left\{l \leq Q_{\tau}\right\}}{f_{L}\left(Q_{\tau}\right)}=c_{1, \tau} \cdot \mathbb{1}\left\{l>Q_{\tau}\right\}+c_{2, \tau},
$$

where $c_{1, \tau}=1 / f_{L}\left(Q_{\tau}\right)$ and $c_{2, \tau}=Q_{\tau}-c_{1, \tau} \cdot(1-\tau)$. As $\mathbb{E}\left[\mathbb{1}\left\{l>Q_{\tau}\right\}\right]=\operatorname{Pr}\left(L>Q_{\tau}\right)=1-\tau$, it follows that $E\left[R I F\left(l ; Q_{\tau}\right)\right]=c_{1, \tau} \operatorname{Pr}\left(L>Q_{\tau}\right)+c_{2, \tau}=Q_{\tau}$. By the law of iterated expectations, we have

$$
E\left[R I F\left(l ; Q_{\tau}\right)\right]=\mathbb{E}_{X}\left\{\mathbb{E}\left[R I F\left(l ; Q_{\tau}\right)\right] \mid X\right\},
$$

which justifies running a linear regression of the binary outcome variable $\mathbb{1}\left\{l>Q_{\tau}\right\}$ on $X$ (see Fortin et al. (2011) and Firpo et al. (2009) for details). We run RIF-regressions for the $10^{\text {th }}$ $(\tau=0.1)$ and $90^{t h}(\tau=0.9)$ percentiles $Q_{\tau}$ as well as the median $(\tau=0.5)$. This decomposition at different points of the distribution of financial literacy score allows us to investigate whether individual characteristics and institutions matter in different ways across the financial literacy distribution. See subsections 4.3 and 4.4 for a discussion of results.

\subsection{Coefficient effects and institutions}

In this stage of our framework, we correlate the unexplained parts of the gaps, estimated from the B-O analysis $\chi_{c}$, with selected macroeconomic indicators that have been shown to be relevant for the financial literacy at the country-level (Jappelli, 2010). Our chosen aggregate

\footnotetext{
${ }^{2}$ An alternative way to perform a quantile decomposition analysis, which has been applied in several empirical papers, is the approach suggested by Machado and Mata (2005).
} 
indicators include GDP per capita, share of internet users, life expectancy, (gross) enrolment ratio to secondary school, stock market capitalization, PISA match test score, and social contributions rate (a proxy for welfare state). For a detailed description, see Table 4. Formally, we can write this country-level relationship as a regression of our estimated unexplained parts on macroeconomic indicators,

$$
\chi=\alpha+\phi z+\varepsilon, \quad \forall z \in Z
$$

where $\alpha$ is a constant, $z$ refers to one country level macroeconomic indicator of indicators $Z$,

and $\phi$ is the according slope parameter. $\hat{\phi}$ is then our estimate of the relationship between unexplained parts $\chi$ and macroeconomic variable $z \in Z$. See subsection 4.4 for results and discussion of this step.

[Enter Table 4 here]

\section{Results}

In this section we first discuss average financial literacy across countries and socioeconomic characteristics in subsection 4.1. We then present our estimates of the conditional expectation function of financial literacy, controlling for country level fixed effects in subsection 4.2. Subsection 4.3 includes the core of our analysis, the decomposition of cross-country differences in financial literacy into parts explainable by individual characteristics and an unexplained part. We also decompose beyond the mean at the 10th and 90th percentile of the financial literacy distribution and the median. We employ the unexplained parts to correlate them with macroeconomic and institutional variables to shed further light on potential drivers of differences in financial literacy in subsection 4.4. In Appendix B we deliver a robustness check, in which we add the potentially endogenous variables capturing experience presented in section 2 to the analyses.

\subsection{Socioeconomic characteristics}

Table 5 shows average financial literacy by socioeconomic characteristics and countries. In all countries men - on average - obtained higher financial literacy scores than women. Higher education goes along with higher financial literacy scores in all countries as well. Financial literacy seems to increase initially with age and to decrease again for the elderly. However, this pattern does not prevail in all countries (Brazil and Jordan). Regarding employment, in many countries ( 8 out of 12 ) the self-employed have marginally higher financial literacy than the employed. 
[Enter table 5 here]

\subsection{Determinants of financial literacy}

Table 6 shows different estimates of the conditional expectation function (CEF) of financial literacy. It can be interpreted as a predictive production function of financial literacy. We estimate two specifications with basic socio-economic characteristics (see Table 3) as explanatory variables: (1) without country fixed effects, (2) with country fixed effects. Note, that due to missing values in some of the explanatory variables our sample reduces from 15,388 observations to 12,298 .

The results with regard to the predictive effects of individual characteristics are robust to adding country fixed effects. The income buffer dummy, which is a raw measure of financial wealth is positively related to financial literacy and translates to about 0.3 to 0.6 (depending on specification) correct answers (out of the 7) more for households with a financial buffer of 3 monthly incomes or more. The gender gap usually found in work on financial literacy is clearly visible. Women score on average about 0.4 points less. Singles also tend to have slightly lower scores. However, the coefficients are not always statistically and more importantly never economically significant. Individuals with university degrees score about 0.4 to 0.7 questions better. The hump shaped age pattern we found in the descriptive tables is confirmed in the estimation of the CEF. The lowest age category scores lower than the oldest, but the age category between 50-69 scores even higher. Whereas the employed score significantly higher than people not working this is less clear for the self-employed and the retired. However, the coefficients of employed and self-employed are not significantly different from each other.

[Enter Table 6 here]

\subsection{Decomposition analysis}

Results from the Blinder-Oaxaca (B-O) decomposition analysis are shown in Table $7 .^{3}$ As outlined in section 3, we use Finland as a reference country. The largest gaps (larger than

\footnotetext{
${ }^{3}$ Note that the means of financial literacy are slightly different from the unconditional means due to the missing information on individual characteristics and experience. However, given the fact that the total sample size is still 12,298 observations in the case of individual characteristics and 10,810 observations in the case of individual characteristics and experience (see Appendix B), the missing pattern is not highly correlated with our covariate set and our covariate set contains exclusively dummy variables, which means that we do not have a large amount of linear extrapolation but rather look at a set of conditional group specific means of combinations of dummies, and we are confident using the standard listwise deletion approach. Our RIF-regression based approach for the median serves as a robustness check as the median is a robust statistic in the sense that it has a bounded influence function, which means that it is less exposed to missing observations.
} 
15\%) are observed in Croatia, Russia, Jordan and Brazil. But also the UK and Hungary show relatively large gaps compared to Finland (larger than 10\%). Austria and Canada still show gaps above 5\%, whereas Germany and the Netherlands hardly show relevant deviations. Hong Kong exceeds average financial literacy in Finland.

In some countries differences in observable individual characteristics with Finland significantly dampen the gap (Canada, Jordan, The Netherlands and the UK), while for other countries the gap is significantly larger because of differences in individual characteristics (Austria, Brazil, Croatia, Hungary and Russia). In the case of these countries between about $11 \%$ (Russia) and 60\% (Austria) is explained by differences in individual characteristics. That means that if differences due to differences in the share of characteristics in the population are filtered out and only within characteristic differences are considered, the gap reduces by this amount. In the same way the gap widens for countries where characteristics dampen the unconditional observed differences. In Germany the gap is not significantly different from Finland, whereas in Hong Kong individual characteristics do not significantly explain part of the higher score in Hong Kong.

All in all, it is rather obvious that individual characteristics matter when comparing financial literacy across countries. It is rather important to have "apples to apples" comparison to design policies in an informed way. In the case of differences in educational attainment this is rather obvious. On the one hand, a gap in average financial literacy may exist across countries within education groups; this would be the case if financial literacy differed among the highly educated in country A versus country B. On the other hand, a gap could also exist across countries even if the financial literacy within education groups is the same across countries. This could be the case if the share of, say, highly educated individuals is higher in country A than in country B. From a policy perspective these gaps need to be dealt with differently. Whereas the first raises the question of why similarly educated groups have different financial literacy, given the second financial literacy might just be increased by increasing educational attainment.

\section{[Enter Table 7 here]}

Given the different distributions of the financial literacy score across countries (Figure 1), we decompose these distributions by means of RIF-regressions as outlined in subsection 3.5. Results of the RIF-regression based B-O quantile decomposition analysis (for the 10th, 50th, and 90th percentile) are presented in Table 8. The RIF-regression based approach for the median serves also as a robustness check for the standard B-0 decomposition at the mean, as 
the median is a robust statistic in the sense that it has a bounded influence function, which means that it is less exposed to missing observations.

[Enter Table 8 here]

The B-O decomposition analysis at the median of financial literacy (Table 8) confirms the results of the decomposition at the mean (Table 7). However, results differ substantially for the upper (90th percentile) and lower (10th percentile) part of the distributions of the financial literacy score, pointing towards different mechanisms in place at different points of the distribution. Gaps in percentage are larger and individual characteristics can explain fewer of these observed gaps at the bottom (p10) than at the top (p90). Especially interesting is the fact that the additional explanatory power of experience tends to explain relatively more of the gap at higher levels of financial literacy and especially for countries which lag behind literacy levels of Finland (see tables B.2 and B.3).

\subsection{Unexplained gaps of financial literacy and the role of institutions}

In this section we examine the role of institutions in explaining the unexplained parts (neither by individual characteristics nor by experience) of the gaps in financial literacy score across the countries compared. Following Christelis et al. (2013), we correlate the unexplained parts (coefficient effects) obtained from the mean and quantile B-O decomposition analysis with the selected macroeconomic variables influencing populations' financial literacy. We consider a set of aggregate indicators which have been shown as important determinants of financial literacy at country-level. Following Jappelli (2010), we consider GDP per capita, share of internet users, (gross) enrolment ratio to secondary school, life expectancy, PISA math test scores, stock market capitalization, and social contributions rate.

Similarly to Christelis et al. (2013), we argue that the unexplained component of the gap in financial literacy might be attributed to different economic environments of countries. As an example, one could think of the education system's quality in the particular country which can have important implications for the population's financial literacy, which we proxy by an indicator on the PISA math test. According to Ciaian and Pokrivčák (2005), crucial sectors for economic development and human capital accumulation including the development of education systems in many transition countries have been lagging behind compared to Western European countries during the transition from a centrally-planned to a market economy. The unexplained part could also be interpreted as impacts of historic (behavioral) experiences of the market economy which in turn could influence the financial literacy of individuals - proxied by an indicator on the stock market capitalization (e.g. Jappelli, 2010). 
Having a glance at Figure 2 one can infer the main finding from the distributional analysis (see subsection 4.3) and its relation to institutional differences. Overall, the unexplained part of the gaps estimated from the B-O analysis at the mean decreases with countries being institutionally closer to our benchmark category, Finland. This finding holds for the whole distribution of the financial literacy score, the 10th, 50th, and 90th percentile (see figures B.1 and B.2 in Appendix B). For a detailed discussion on how experience might matter differently across the distribution of financial literacy see Appendix B.

\section{[Enter Figure 2 here]}

As the last step of our empirical analysis, we examine which institutions matter the most for explaining the coefficient effects (the unexplained part of the gaps) estimated from the B-O analysis. To do so, we regress the unexplained part of the gaps estimated from the mean and quantile decomposition analysis, on a set of macroeconomic indicators whose values have been standardized (i.e. de-meaned and divided by their standard deviations).

A ranking of the importance of different institutions with regards to explaining the coefficient effects is presented in Table 9. Overall, we can see that all the macroeconomic and institutional variables under consideration are negatively correlated with unexplained differences in financial literacy. The higher the GDP per capita, enrolment to secondary school ratio, share of internet users, life expectancy, social contributions, PISA math results, and stock market capitalization, the lower the unexplained differences with Finland. As Finland also ranks among the highest in all these country level indicators, one can also interpret this result as unexplained differences in financial literacy being lower if institutional differences are smaller (results including experience presented in Appendix B , Table B.4).

\section{[Enter Table 9 here]}

Life expectancy shows the largest correlation with the unexplained part of the financial literacy gaps. Life expectancy, as well as GDP per capita, can be considered as indicators for the general level of development. Also the share of internet users is predictive for the size of the unexplained gaps. The PISA math test score - an indicator which proxies the quality of education system in the particular country - also turns out to be highly important for explaining financial literacy gaps.

All in all, these results point to the importance of the environment when discussing crosscountry differences in financial literacy. Environment not only matters in a direct way, by 
influencing financial literacy or creating more need - in the case of a smaller welfare state for financial literacy, but also indirectly, by allowing individual characteristics to translate in different ways to financial literacy. As an example one can imagine that an individual with higher educational attainment might be able to acquire financial literacy at lower cost with internet access rather than without. Or as another example, the need to engage in financial markets might be higher in a country where the need for private pension savings is higher. 


\section{Conclusion}

The literature observes large differences in average financial literacy across countries (Lusardi and Mitchell, 2014; Standard and Poor's, 2014). While these observed differences arguably influence policies, the populations in the different countries are not homogenous. So far, it had been unknown to what extent the observed differences are country-specific or driven by differences in the individual characteristics of the (sampled) population. To design the right policies, it is of the utmost importance to understand the reasons for observed differences of cross-country financial literacy gaps.

By examining recently compiled harmonized OECD/INFE microdata on the financial literacy of individuals in 12 countries along with country level indicators, we delivered estimates of how much of these observed differences are due to differences in the characteristics of the population.

Results indicate that differences in individual characteristics matter considerably. In some countries, differences in observable individual characteristics dampen much of the gap compared to Finland (in particular, Canada, Jordan, The Netherlands, and the UK). For other countries, the gap is significantly larger because of differences in individual characteristics (in this case, Finland versus Austria, Brazil, Croatia, Hungary, and Russia). In the latter set of countries, between about $11 \%$ (Russia) and $60 \%$ (Austria) of the gap is explained by differences in individual characteristics. That means that if differences in financial literacy due to differences in the population's characteristics were filtered out and only within-characteristic differences were considered, the gap would be reduced by this amount. We conclude that individual characteristics should be taken into account when countries are compared and specifically when they are ranked as in the OECD/INFE report. It is rather important to have an "apples to apples" comparison to design policies in an informed way.

A variety of robustness checks including extensions of the set of controls by potentially endogenous variables covering experience as well as analyses beyond the mean for different points of the distribution of financial literacy confirmed our results.

In the second stage of the analysis, we correlated the unexplained parts of the financial literacy gaps (not explained by varying individual characteristics) obtained from decomposition analysis with macroeconomic and institutional country-level indicators. Following Jappelli (2010), we considered a set of indicators such as GDP per capita, share of internet users, (gross) enrolment ratio to secondary school, life expectancy, stock market capitalization, PISA math test score, and social contributions rate (proxy for welfare state). Confirming the find- 
ings of Jappelli (2010), our results point to the importance of a country's institutional context when discussing cross-country differences in financial literacy. However, while Jappelli (2010) based his analysis on a subset of individuals (working in management), our analysis is based on representative samples of individuals. That allows us to show that the importance of institutions is different for individuals with different levels of financial literacy. Those with lower financial literacy are generally not engaged with more complex financial products such as stocks and have less need to make sophisticated financial decisions. For them, financial decisions are instead related to taking loans and making basic day-to-day decisions. Other individuals with higher financial literacy might more likely hold substantial amounts of their wealth in more complex financial products. Targeted policies might differ for these two groups.

It is important to emphasize that the country-level results obtained from the decomposition analysis and consequent linking to different economic environments do not necessarily imply causality. Despite having this caveat in mind, our results offer interesting policy implications. Besides investing in individual-level factors important for human capital development (e.g. education, basic training in finance) it seems that there is room for harmonizing the economic and institutional environment across countries to decrease inequality in financial literacy.

We conclude that taking differences in population characteristics into account when comparing financial literacy across countries is important. If this is not done, it is difficult to draw useful policy conclusions, as it is impossible to disentangle differences based on countryspecific variation from those based on variation in individual-level characteristics. Country rankings such as those presented in the OECD/INFE report are not very meaningful with regard to policy conclusions if differences stemming from basic individual characteristics cannot be identified. 


\section{References}

Atkinson, Adele and Flore-Anne Messy, "Assessing financial literacy in 12 countries: an OECD/INFE international pilot exercise," Journal of Pension Economics and Finance, $2011,10(04), 657-665$.

Badarinza, Cristian, John Y Campbell, and Tarun Ramadorai, "International comparative household finance," Annual Review of Economics, 2016, 8, 111-144.

Blinder, Alan S, "Wage discrimination: reduced form and structural estimates," Journal of Human Resources, 1973, 8 (4), 436-455.

Bover, Olympia, Martin Schürz, Jiri Slacalek, and Federica Teppa, "Eurosystem Household Finance and Consumption Survey: Main Results on Assets, Debt, and Saving," International Journal of Central Banking, 2016, 12 (2), 1-13.

Campbell, John Y, "Household finance," The Journal of Finance, 2006, 61 (4), 1553-1604.

Christelis, Dimitris, Dimitris Georgarakos, and Michael Haliassos, "Differences in portfolios across countries: Economic environment versus household characteristics," Review of Economics and Statistics, 2013, 95 (1), 220-236.

Ciaian, Pavel and Ján Pokrivčák, "Why Some Sectors of Transition Economies are less Reformed than Others? The Case of Research and Education," Technical Report, EERI Research Paper Series 2005.

Fernandes, Daniel, John G Lynch Jr, and Richard G Netemeyer, "Financial literacy, financial education, and downstream financial behaviors," Management Science, 2014, 60 (8), 1861-1883.

Firpo, Sergio, Nicole M. Fortin, and Thomas Lemieux, "Decomposing Wage Distributions using Recentered Influence Function Regressions," 2007.

_, _, and _, "Unconditional quantile regressions," Econometrica, 2009, 77 (3), 953-973.

Fonseca, Raquel, Kathleen J Mullen, Gema Zamarro, and Julie Zissimopoulos, "What explains the gender gap in financial literacy? The role of household decision making," Journal of Consumer Affairs, 2012, 46 (1), 90-106.

Fortin, N., T. Lemieux, and S. Firpo, "Decomposition methods in economics," Handbook of Labor Economics, 2011, 4, 1-102.

Hastings, Justine S, Brigitte C Madrian, and William L Skimmyhorn, "Financial Literacy, Financial Education, and Economic Outcomes," Annual Review of Economics, $2013,5(1), 347-73$. 
Jappelli, Tullio, "Economic literacy: An international comparison," The Economic Journal, 2010, 120 (548), F429-F451.

Lusardi, Annamaria and Olivia S Mitchell, "Financial literacy around the world: an overview," Journal of Pension Economics and Finance, 2011, 10 (04), 497-508.

_ and _ , "The economic importance of financial literacy: Theory and evidence," Journal of Economic Literature, 2014, 52 (1), 5-44.

Machado, José AF and José Mata, "Counterfactual decomposition of changes in wage distributions using quantile regression," Journal of Applied Econometrics, 2005, 20 (4), 445-465.

Mathä, Thomas Y, Alessandro Porpiglia, and Michael Ziegelmeyer, "Household wealth in the euro area: The importance of intergenerational transfers, homeownership and house price dynamics," Journal of Housing Economics, 2017, 35, 1-12.

Oaxaca, Ronald, "Male-female wage differentials in urban labor markets," International Economic Review, 1973, 14 (3), 693-709.

OECD, "Results: Students and Money: Financial Literacy Skills for the 21st Century (Volume VI), PISA," 2013.

_, OECD/INFE International Survey of Adult Financial Literacy Competencies, Organisation for Economic Co-operation and Development, 2016.

Standard and Poor's, "Global Financial Literacy Survey," 2014. 


\section{$6 \quad$ Figures and tables}

Figure 1: Distribution of financial literacy score across countries

(a) Austria

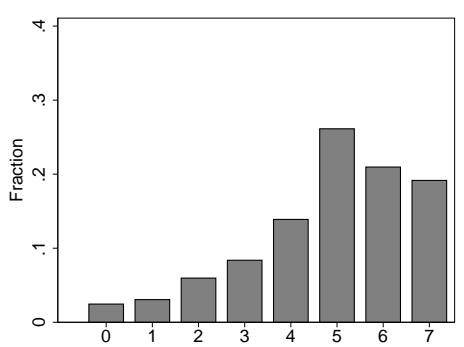

(d) Croatia

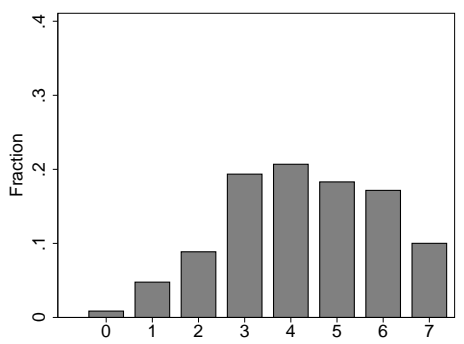

(g) Hong Kong

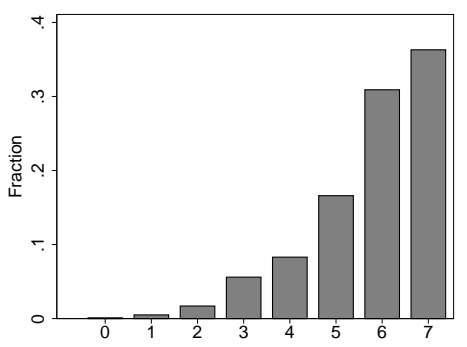

(j) The Netherlands

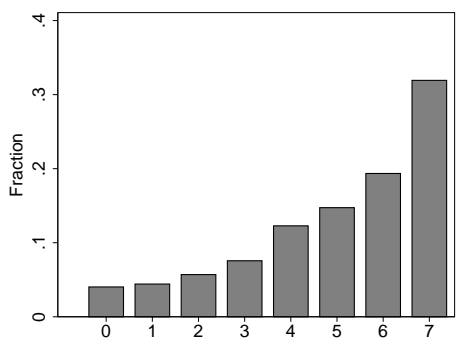

(b) Brazil

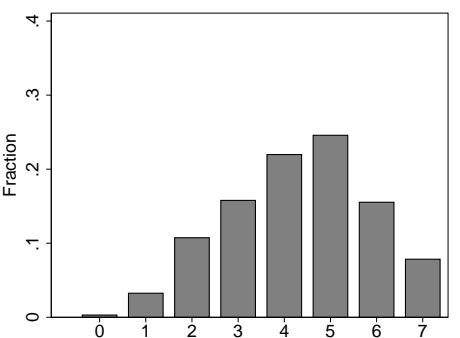

(e) Finland

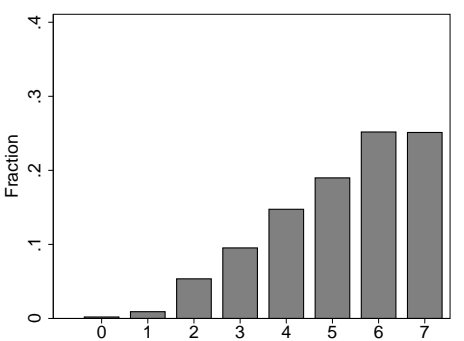

(h) Hungary

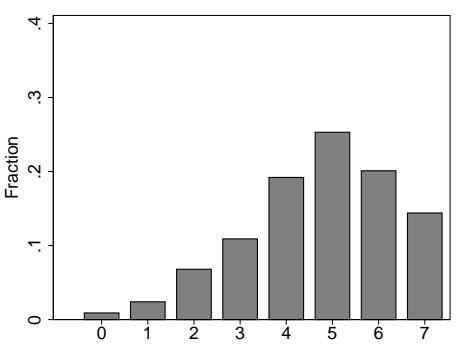

(k) Russia

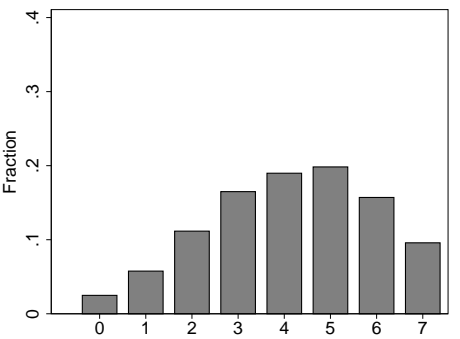

(c) Canada

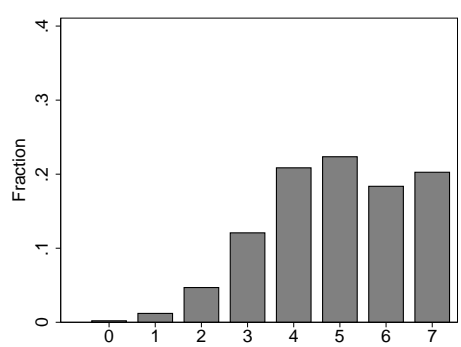

(f) Germany

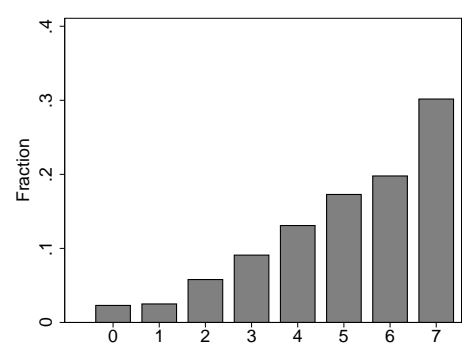

(i) Jordan

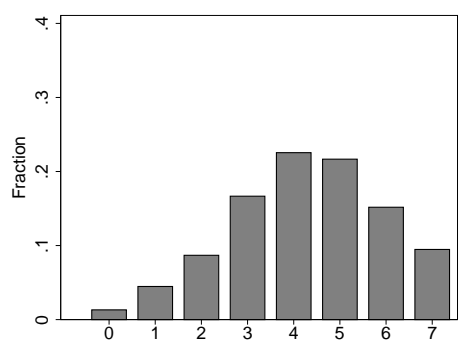

(1) UK

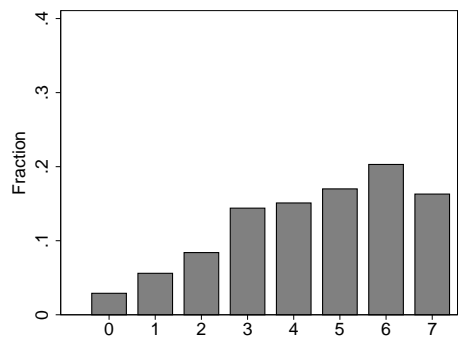

Source: OECD/INFE international survey of adult financial literacy competencies 
Figure 2: Estimated coefficient effects from the mean B-O decomposition versus selected macroeconomic indicators (baseline)

(a) Internet

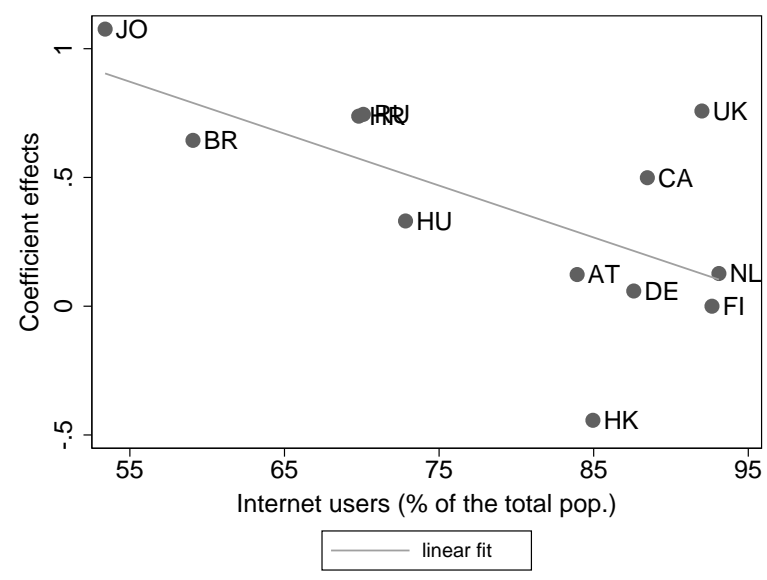

(c) Math in PISA

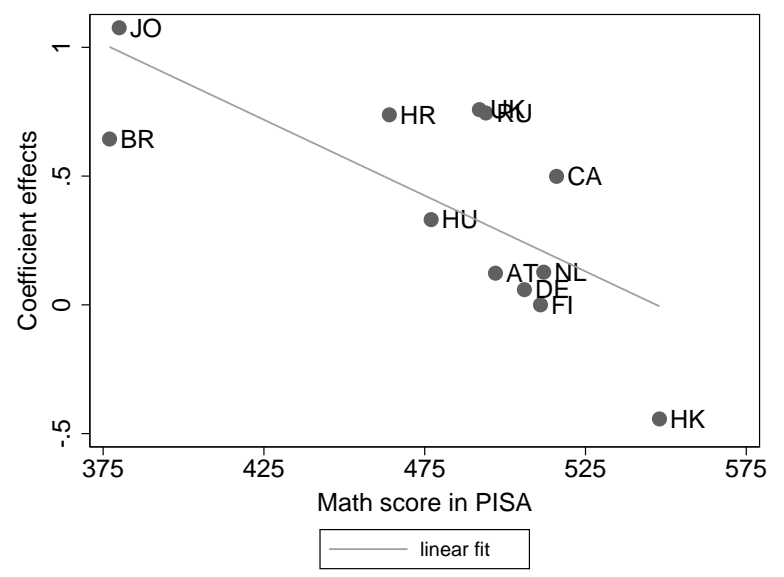

(b) Life expectancy

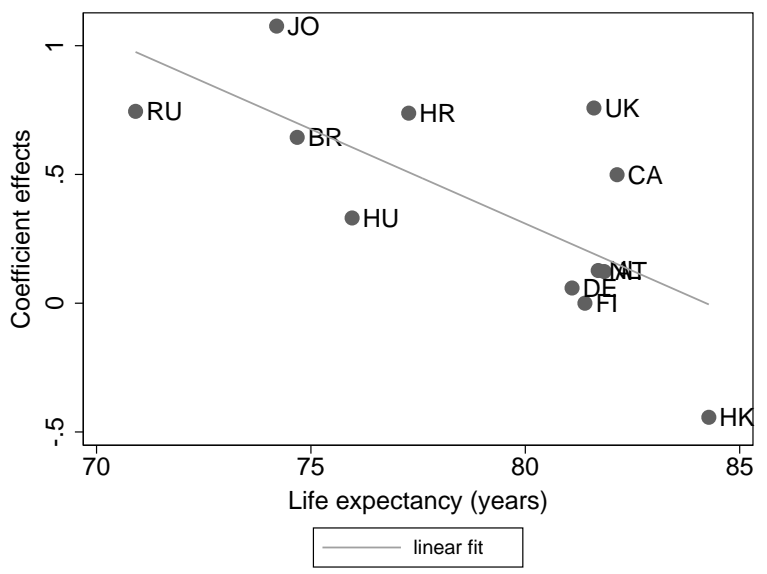

(d) Welfare state

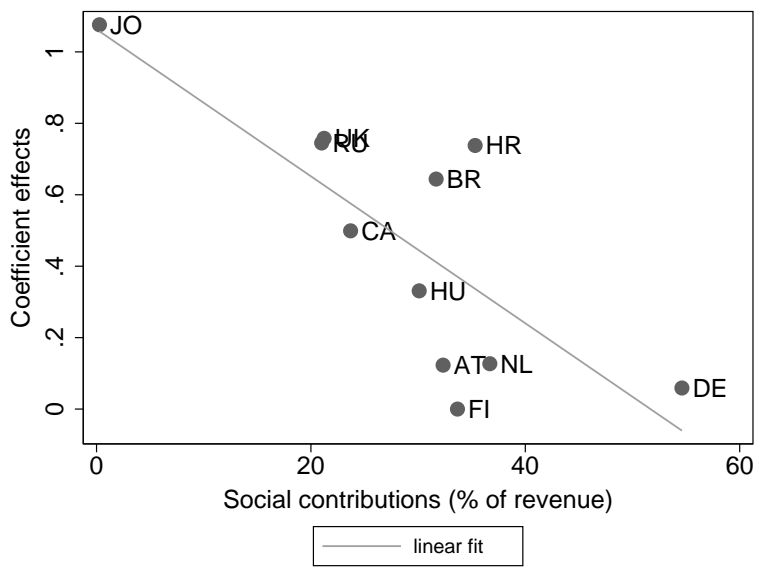

Note: Austria (AT), Brazil (BR), Canada (CA), Croatia (HR), Finland (FI), Germany (DE), Hong Kong (HK), Hungary (HU), Jordan (JO), The Netherlands (NL), Russia (RU), the United Kingdom (UK).

Source: OECD/INFE international survey of adult financial literacy competencies, World Bank data 
Table 1: Survey details

\begin{tabular}{|c|c|c|c|c|c|}
\hline Country & Institution & Date of survey & Type of survey & Sampling method & Sample size \\
\hline Austria & $\begin{array}{l}\text { Oesterreichische National- } \\
\text { bank }\end{array}$ & 2014 & Face-to-face & Stratified sampling & 1,994 \\
\hline Brazil & Banco Central do Brasil & 2015 & Face-to-face & Stratified cluster sampling & 2,002 \\
\hline Canada & $\begin{array}{l}\text { Financial Consumer } \\
\text { Agency of Canada }\end{array}$ & 2015 & Telephone interviews & $\begin{array}{l}\text { Nested quotas using ran- } \\
\text { dom digit dialing }\end{array}$ & 1,002 \\
\hline Croatia & $\begin{array}{l}\text { Croatian National Bank } \\
\text { and Croatian Financial } \\
\text { Services Agency }\end{array}$ & 2015 & Face-to-face & Stratified sampling & 1,049 \\
\hline Finland & $\begin{array}{l}\text { University of Tampere and } \\
\text { University of Vaasa }\end{array}$ & 2014 & Face-to-face & Stratified cluster sampling & 1,533 \\
\hline Germany & Deutsche Bundesbank & 2016 & Telephone interviews & Stratified sampling & 1,001 \\
\hline Hong Kong & Investor Education Center & 2015 & Face-to-face & Stratified sampling & 1,000 \\
\hline Hungary & Magyar Nemzeti Bank & 2015 & Face-to-face & $\begin{array}{l}\text { Quota sample from strat- } \\
\text { ified probability starting } \\
\text { point }\end{array}$ & 1,000 \\
\hline Jordan & INJAZ & 2016 & Face-to-face & Stratified sampling & 1,140 \\
\hline The Netherlands & Money Wise & 2015 & Online interviews & N.A. & 1,018 \\
\hline Russia & $\begin{array}{l}\text { Ministry of Finance of the } \\
\text { Russian Federation }\end{array}$ & 2015 & Face-to-face & Stratified sampling & 1,649 \\
\hline UK & Money Advice Service & 2015 & $\begin{array}{l}30 \% \text { telephone, } 70 \% \text { online } \\
\text { interviews }\end{array}$ & Stratified random sampling & 1,000 \\
\hline
\end{tabular}

Source: OECD/INFE international survey of adult financial literacy competencies 
Table 2: Description of variables used in empirical analysis

\begin{tabular}{|c|c|}
\hline Variable & Description \\
\hline Financial literacy score & $\begin{array}{l}\text { Number of correctly answered financial literacy questions (see Appendix } \\
\text { A for details); score ranging from } 0 \text { to } 7\end{array}$ \\
\hline Income buffer & $\begin{array}{l}\text { Dummy variable: } 1 \text { if an individual has a financial buffer for at least } \\
\text { three months in case he/she loses his/her job (a proxy for wellbeing) }\end{array}$ \\
\hline Gender & Dummy variable: 1 if female and 0 otherwise \\
\hline Single & Dummy variable: 1 if an individual lives alone and 0 otherwise \\
\hline University education & $\begin{array}{l}\text { Dummy variable: } 1 \text { if university education is the highest attained done } \\
\text { and } 0 \text { otherwise }\end{array}$ \\
\hline Age category (18-29) & Dummy variable: 1 if an individual aged from 18 to 29 and 0 otherwise \\
\hline Age category (30-49) & Dummy variable: 1 if an individual aged from 30 to 49 and 0 otherwise \\
\hline Age category (50-69) & Dummy variable: 1 if an individual aged from 50 to 69 and 0 otherwise \\
\hline Age category $(70+)$ & Dummy variable: 1 if an individual aged $70+$ and 0 otherwise \\
\hline Employed & $\begin{array}{l}\text { Dummy variable: } 1 \text { if paid employment (working for someone else) and } \\
0 \text { otherwise }\end{array}$ \\
\hline Self-employed & $\begin{array}{l}\text { Dummy variable: } 1 \text { if self employed (working for him/herself) and } 0 \\
\text { otherwise }\end{array}$ \\
\hline Retired & Dummy variable: 1 if retired and 0 otherwise \\
\hline Other, not-working & $\begin{array}{l}\text { Dummy variable: } 1 \text { if unemployed or not-working (e.g. apprentice, look- } \\
\text { ing for work, looking after home, unable to work due to sickness, student) } \\
\text { and } 0 \text { otherwise }\end{array}$ \\
\hline Having budget & $\begin{array}{l}\text { Dummy variable: } 1 \text { if an individual is responsible for budget and has a } \\
\text { budget and } 0 \text { otherwise }\end{array}$ \\
\hline Active saver & $\begin{array}{l}\text { Dummy variable: } 1 \text { if an individual actively saves in one of the following } \\
\text { schemes (cash at home, savings account, informal savings club, invest- } \\
\text { ment products) and } 0 \text { otherwise }\end{array}$ \\
\hline Holding risky financial assets & $\begin{array}{l}\text { Dummy variable: } 1 \text { if an individual holds shares or bonds in his/her } \\
\text { financial portfolio and } 0 \text { otherwise }\end{array}$ \\
\hline Financial planning & $\begin{array}{l}\text { Dummy variable: } 1 \text { if an individual sets long-term financial goals and } 0 \\
\text { otherwise }\end{array}$ \\
\hline
\end{tabular}

Source: OECD/INFE international survey of adult financial literacy competencies 
Table 3: Summary statistics of variables used in empirical analysis

\begin{tabular}{|c|c|c|c|c|c|c|c|c|c|c|c|c|}
\hline Variable & AT & BR & $\mathrm{CA}$ & HR & FI & DE & HK & $\mathrm{HU}$ & $\mathrm{JO}$ & NL & RU & UK \\
\hline Financial literacy Score & $\begin{array}{c}4.79 \\
(1.80)\end{array}$ & $\begin{array}{c}4.31 \\
(1.55)\end{array}$ & $\begin{array}{c}4.93 \\
(1.54)\end{array}$ & $\begin{array}{c}4.27 \\
(1.67)\end{array}$ & $\begin{array}{c}5.19 \\
(1.56)\end{array}$ & $\begin{array}{c}4.75 \\
(1.95)\end{array}$ & $\begin{array}{c}5.76 \\
(1.32)\end{array}$ & $\begin{array}{c}4.72 \\
(1.62)\end{array}$ & $\begin{array}{c}4.28 \\
(1.65)\end{array}$ & $\begin{array}{c}4.89 \\
(2.06)\end{array}$ & $\begin{array}{c}4.14 \\
(1.79)\end{array}$ & $\begin{array}{c}4.21 \\
(1.86)\end{array}$ \\
\hline \multicolumn{13}{|l|}{ Basic socio-economic characteristics } \\
\hline Income buffer & $\begin{array}{c}0.52 \\
(0.50)\end{array}$ & $\begin{array}{c}0.27 \\
(0.45)\end{array}$ & $\begin{array}{c}0.69 \\
(0.46)\end{array}$ & $\begin{array}{c}0.32 \\
(0.47)\end{array}$ & $\begin{array}{c}0.57 \\
(0.50)\end{array}$ & $\begin{array}{c}0.69 \\
(0.46)\end{array}$ & $\begin{array}{c}0.68 \\
(0.47)\end{array}$ & $\begin{array}{c}0.32 \\
(0.47)\end{array}$ & $\begin{array}{c}0.26 \\
(0.44)\end{array}$ & $\begin{array}{c}0.57 \\
(0.50)\end{array}$ & $\begin{array}{c}0.24 \\
(0.43)\end{array}$ & $\begin{array}{c}0.58 \\
(0.49)\end{array}$ \\
\hline Gender & $\begin{array}{c}0.52 \\
(0.50)\end{array}$ & $\begin{array}{c}0.52 \\
(0.50)\end{array}$ & $\begin{array}{c}0.52 \\
(0.50)\end{array}$ & $\begin{array}{c}0.53 \\
(0.50)\end{array}$ & $\begin{array}{c}0.50 \\
(0.50)\end{array}$ & $\begin{array}{c}0.54 \\
(0.50)\end{array}$ & $\begin{array}{c}0.54 \\
(0.50)\end{array}$ & $\begin{array}{c}0.53 \\
(0.50)\end{array}$ & $\begin{array}{c}0.44 \\
(0.50)\end{array}$ & $\begin{array}{c}0.50 \\
(0.50)\end{array}$ & $\begin{array}{c}0.53 \\
(0.50)\end{array}$ & $\begin{array}{c}0.52 \\
(0.50)\end{array}$ \\
\hline Single & $\begin{array}{c}0.34 \\
(0.47)\end{array}$ & $\begin{array}{c}0.09 \\
(0.28)\end{array}$ & $\begin{array}{c}0.18 \\
(0.38)\end{array}$ & $\begin{array}{c}0.17 \\
(0.38)\end{array}$ & $\begin{array}{c}0.30 \\
(0.46)\end{array}$ & $\begin{array}{c}0.22 \\
(0.42)\end{array}$ & $\begin{array}{c}0.06 \\
(0.24)\end{array}$ & $\begin{array}{c}0.16 \\
(0.37)\end{array}$ & $\begin{array}{c}0.09 \\
(0.29)\end{array}$ & $\begin{array}{c}0.21 \\
(0.41)\end{array}$ & $\begin{array}{c}0.16 \\
(0.36)\end{array}$ & $\begin{array}{c}0.23 \\
(0.42)\end{array}$ \\
\hline University education & $\begin{array}{c}0.10 \\
(0.30)\end{array}$ & $\begin{array}{c}0.09 \\
(0.29)\end{array}$ & $\begin{array}{c}0.45 \\
(0.50)\end{array}$ & $\begin{array}{c}0.18 \\
(0.38)\end{array}$ & $\begin{array}{c}0.27 \\
(0.44)\end{array}$ & $\begin{array}{c}0.16 \\
(0.37)\end{array}$ & $\begin{array}{c}0.20 \\
(0.40)\end{array}$ & $\begin{array}{c}0.19 \\
(0.39)\end{array}$ & $\begin{array}{c}0.62 \\
(0.49)\end{array}$ & $\begin{array}{c}0.38 \\
(0.49)\end{array}$ & $\begin{array}{c}0.28 \\
(0.45)\end{array}$ & $\begin{array}{c}0.31 \\
(0.46)\end{array}$ \\
\hline Age category (18-29) & $\begin{array}{c}0.21 \\
(0.41)\end{array}$ & $\begin{array}{c}0.26 \\
(0.44)\end{array}$ & $\begin{array}{c}0.19 \\
(0.39)\end{array}$ & $\begin{array}{c}0.20 \\
(0.40)\end{array}$ & $\begin{array}{c}0.24 \\
(0.43)\end{array}$ & $\begin{array}{c}0.18 \\
(0.38)\end{array}$ & $\begin{array}{c}0.19 \\
(0.39)\end{array}$ & $\begin{array}{c}0.20 \\
(0.40)\end{array}$ & $\begin{array}{c}0.47 \\
(0.50)\end{array}$ & $\begin{array}{c}0.18 \\
(0.38)\end{array}$ & $\begin{array}{c}0.24 \\
(0.43)\end{array}$ & $\begin{array}{c}0.18 \\
(0.39)\end{array}$ \\
\hline Age category (30-49) & $\begin{array}{c}0.35 \\
(0.48)\end{array}$ & $\begin{array}{c}0.43 \\
(0.49)\end{array}$ & $\begin{array}{c}0.35 \\
(0.48)\end{array}$ & $\begin{array}{c}0.35 \\
(0.48)\end{array}$ & $\begin{array}{c}0.38 \\
(0.48)\end{array}$ & $\begin{array}{c}0.35 \\
(0.48)\end{array}$ & $\begin{array}{c}0.39 \\
(0.49)\end{array}$ & $\begin{array}{c}0.36 \\
(0.48)\end{array}$ & $\begin{array}{c}0.39 \\
(0.49)\end{array}$ & $\begin{array}{c}0.37 \\
(0.48)\end{array}$ & $\begin{array}{c}0.36 \\
(0.48)\end{array}$ & $\begin{array}{c}0.34 \\
(0.47)\end{array}$ \\
\hline Age category (50-69) & $\begin{array}{c}0.29 \\
(0.45)\end{array}$ & $\begin{array}{c}0.27 \\
(0.45)\end{array}$ & $\begin{array}{c}0.38 \\
(0.48)\end{array}$ & $\begin{array}{c}0.33 \\
(0.47)\end{array}$ & $\begin{array}{c}0.30 \\
(0.46)\end{array}$ & $\begin{array}{c}0.32 \\
(0.47)\end{array}$ & $\begin{array}{c}0.34 \\
(0.48)\end{array}$ & $\begin{array}{c}0.33 \\
(0.47)\end{array}$ & $\begin{array}{c}0.13 \\
(0.34)\end{array}$ & $\begin{array}{c}0.37 \\
(0.48)\end{array}$ & $\begin{array}{c}0.36 \\
(0.48)\end{array}$ & $\begin{array}{c}0.34 \\
(0.47)\end{array}$ \\
\hline Age category $(70+)$ & $\begin{array}{c}0.15 \\
(0.36)\end{array}$ & $\begin{array}{c}0.04 \\
(0.20)\end{array}$ & $\begin{array}{c}0.09 \\
(0.28)\end{array}$ & $\begin{array}{c}0.12 \\
(0.32)\end{array}$ & $\begin{array}{c}0.09 \\
(0.28)\end{array}$ & $\begin{array}{c}0.15 \\
(0.36)\end{array}$ & $\begin{array}{c}0.07 \\
(0.26)\end{array}$ & $\begin{array}{c}0.10 \\
(0.30)\end{array}$ & $\begin{array}{c}0.01 \\
(0.09)\end{array}$ & $\begin{array}{c}0.08 \\
(0.27)\end{array}$ & $\begin{array}{c}0.03 \\
(0.17)\end{array}$ & $\begin{array}{c}0.14 \\
(0.35)\end{array}$ \\
\hline Employed & $\begin{array}{c}0.49 \\
(0.50)\end{array}$ & $\begin{array}{c}0.30 \\
(0.46)\end{array}$ & $\begin{array}{c}0.50 \\
(0.50)\end{array}$ & $\begin{array}{c}0.42 \\
(0.49)\end{array}$ & $\begin{array}{c}0.40 \\
(0.49)\end{array}$ & $\begin{array}{c}0.47 \\
(0.50)\end{array}$ & $\begin{array}{c}0.56 \\
(0.50)\end{array}$ & $\begin{array}{c}0.51 \\
(0.50)\end{array}$ & $\begin{array}{c}0.38 \\
(0.49)\end{array}$ & $\begin{array}{c}0.46 \\
(0.50)\end{array}$ & $\begin{array}{c}0.61 \\
(0.49)\end{array}$ & $\begin{array}{c}0.52 \\
(0.50)\end{array}$ \\
\hline Self-employed & $\begin{array}{c}0.07 \\
(0.25)\end{array}$ & $\begin{array}{c}0.33 \\
(0.47)\end{array}$ & $\begin{array}{c}0.10 \\
(0.30)\end{array}$ & $\begin{array}{c}0.07 \\
(0.25)\end{array}$ & $\begin{array}{c}0.06 \\
(0.24)\end{array}$ & $\begin{array}{c}0.08 \\
(0.27)\end{array}$ & $\begin{array}{c}0.04 \\
(0.19)\end{array}$ & $\begin{array}{c}0.05 \\
(0.22)\end{array}$ & $\begin{array}{c}0.13 \\
(0.34)\end{array}$ & $\begin{array}{c}0.07 \\
(0.25)\end{array}$ & $\begin{array}{c}0.08 \\
(0.27)\end{array}$ & $\begin{array}{c}0.07 \\
(0.26)\end{array}$ \\
\hline Retired & $\begin{array}{c}0.28 \\
(0.45)\end{array}$ & $\begin{array}{c}0.12 \\
(0.32)\end{array}$ & $\begin{array}{c}0.20 \\
(0.40)\end{array}$ & $\begin{array}{c}0.26 \\
(0.44)\end{array}$ & $\begin{array}{c}0.25 \\
(0.43)\end{array}$ & $\begin{array}{c}0.27 \\
(0.44)\end{array}$ & $\begin{array}{c}0.13 \\
(0.34)\end{array}$ & $\begin{array}{c}0.25 \\
(0.43)\end{array}$ & $\begin{array}{c}0.04 \\
(0.18)\end{array}$ & $\begin{array}{c}0.17 \\
(0.38)\end{array}$ & $\begin{array}{c}0.19 \\
(0.39)\end{array}$ & $\begin{array}{c}0.24 \\
(0.43)\end{array}$ \\
\hline Other, not-working & $\begin{array}{c}0.17 \\
(0.38)\end{array}$ & $\begin{array}{c}0.24 \\
(0.43) \\
\end{array}$ & $\begin{array}{c}0.20 \\
(0.40)\end{array}$ & $\begin{array}{c}0.26 \\
(0.44)\end{array}$ & $\begin{array}{c}0.29 \\
(0.45)\end{array}$ & $\begin{array}{c}0.18 \\
(0.39)\end{array}$ & $\begin{array}{c}0.27 \\
(0.45)\end{array}$ & $\begin{array}{c}0.19 \\
(0.39)\end{array}$ & $\begin{array}{c}0.45 \\
(0.50)\end{array}$ & $\begin{array}{c}0.30 \\
(0.46)\end{array}$ & $\begin{array}{c}0.13 \\
(0.33)\end{array}$ & $\begin{array}{c}0.16 \\
(0.37)\end{array}$ \\
\hline Additional variables ce & & & & & & & & & & & & \\
\hline Having budget & $\begin{array}{c}0.28 \\
(0.45)\end{array}$ & $\begin{array}{c}0.36 \\
(0.48)\end{array}$ & $\begin{array}{c}0.58 \\
(0.49)\end{array}$ & $\begin{array}{c}0.63 \\
(0.48)\end{array}$ & $\begin{array}{c}0.61 \\
(0.49)\end{array}$ & $\begin{array}{c}0.32 \\
(0.47)\end{array}$ & $\begin{array}{c}0.55 \\
(0.50)\end{array}$ & $\begin{array}{c}0.24 \\
(0.43)\end{array}$ & $\begin{array}{c}0.48 \\
(0.50)\end{array}$ & $\begin{array}{c}0.39 \\
(0.49)\end{array}$ & $\begin{array}{c}0.47 \\
(0.50)\end{array}$ & $\begin{array}{c}0.51 \\
(0.50)\end{array}$ \\
\hline Active saver & $\begin{array}{c}0.68 \\
(0.47)\end{array}$ & $\begin{array}{c}0.30 \\
(0.46)\end{array}$ & $\begin{array}{c}0.79 \\
(0.40)\end{array}$ & $\begin{array}{c}0.63 \\
(0.48)\end{array}$ & $\begin{array}{c}0.61 \\
(0.49)\end{array}$ & $\begin{array}{c}0.67 \\
(0.47)\end{array}$ & $\begin{array}{c}0.73 \\
(0.44)\end{array}$ & $\begin{array}{c}0.27 \\
(0.44)\end{array}$ & $\begin{array}{c}0.71 \\
(0.45)\end{array}$ & $\begin{array}{c}0.71 \\
(0.45)\end{array}$ & $\begin{array}{c}0.55 \\
(0.50)\end{array}$ & $\begin{array}{c}0.72 \\
(0.45)\end{array}$ \\
\hline Holding risky financial assets & $\begin{array}{c}0.12 \\
(0.33)\end{array}$ & $\begin{array}{c}0.01 \\
(0.09)\end{array}$ & $\begin{array}{c}0.46 \\
(0.50)\end{array}$ & $\begin{array}{c}0.13 \\
(0.33)\end{array}$ & $\begin{array}{c}0.30 \\
(0.46)\end{array}$ & $\begin{array}{c}0.29 \\
(0.46)\end{array}$ & $\begin{array}{c}0.38 \\
(0.48)\end{array}$ & $\begin{array}{c}0.05 \\
(0.22)\end{array}$ & $\begin{array}{c}0.14 \\
(0.34)\end{array}$ & $\begin{array}{c}0.09 \\
(0.28)\end{array}$ & $\begin{array}{c}0.02 \\
(0.14)\end{array}$ & $\begin{array}{c}0.37 \\
(0.48)\end{array}$ \\
\hline Financial planning & $\begin{array}{c}0.63 \\
(0.48)\end{array}$ & $\begin{array}{c}0.45 \\
(0.50)\end{array}$ & $\begin{array}{c}0.58 \\
(0.49)\end{array}$ & $\begin{array}{c}0.45 \\
(0.50)\end{array}$ & $\begin{array}{c}0.74 \\
(0.44)\end{array}$ & $\begin{array}{c}0.59 \\
(0.49)\end{array}$ & $\begin{array}{c}0.58 \\
(0.49)\end{array}$ & $\begin{array}{c}0.43 \\
(0.49)\end{array}$ & $\begin{array}{c}0.61 \\
(0.49)\end{array}$ & $\begin{array}{c}0.39 \\
(0.49)\end{array}$ & $\begin{array}{c}0.47 \\
(0.50)\end{array}$ & $\begin{array}{c}0.45 \\
(0.50)\end{array}$ \\
\hline
\end{tabular}

Note: Summary statistics computed using survey weights except Jordan (JO) and Russia (RU), where survey weights are not available. Standard deviations presented in parentheses.

Source: OECD/INFE international survey of adult financial literacy competencies 
Table 4: Selected country-level indicators relevant for financial literacy

\begin{tabular}{|c|c|c|c|c|c|c|c|}
\hline Country & $\begin{array}{c}\text { GDP per } \\
\text { capita (current } \\
\text { \$USD) }\end{array}$ & $\begin{array}{c}\text { Internet users } \\
\text { (\% of the } \\
\text { population) }\end{array}$ & $\begin{array}{c}\text { Life } \\
\text { expectancy } \\
\text { (years) }\end{array}$ & $\begin{array}{c}\text { Enrolment } \\
\text { ratio, upper } \\
\text { secondary (\%) }\end{array}$ & $\begin{array}{c}\text { Stock market } \\
\text { total value to } \\
\text { GDP (\%) }\end{array}$ & $\begin{array}{c}\text { Social } \\
\text { contributions } \\
\text { (\% of revenue) }\end{array}$ & $\begin{array}{c}\text { Math score in } \\
\text { the PISA } \\
\text { survey }\end{array}$ \\
\hline Austria & 43,665 & 83.93 & 81.84 & 95.75 & 7.33 & 32.33 & 497 \\
\hline Brazil & 8,757 & 59.08 & 74.68 & 90.97 & 31.19 & 31.68 & 377 \\
\hline Canada & 43,316 & 88.47 & 82.14 & 119.30 & 77.59 & 23.70 & 516 \\
\hline Croatia & 11,580 & 69.80 & 77.28 & 97.66 & 1.25 & 35.32 & 464 \\
\hline Finland & 42,405 & 92.65 & 81.39 & 115.23 & 56.61 & 33.67 & 511 \\
\hline Germany & 41,177 & 87.59 & 81.09 & 106.68 & 38.25 & 54.61 & 506 \\
\hline Hong Kong & 42,351 & 84.95 & 84.28 & 113.22 & 478.70 & N.A. & 548 \\
\hline Hungary & 12,366 & 72.83 & 75.96 & 102.67 & 10.00 & 30.10 & 477 \\
\hline Jordan & 4,096 & 53.40 & 74.20 & 77.88 & 10.73 & 0.27 & 380 \\
\hline The Netherlands & 44,293 & 93.10 & 81.70 & 124.47 & 54.45 & 36.69 & 512 \\
\hline Russia & 9,329 & 70.10 & 70.91 & 98.77 & 20.26 & 21.00 & 494 \\
\hline UK & 43,930 & 92.00 & 81.60 & 83.20 & 103.06 & 21.23 & 492 \\
\hline
\end{tabular}

Source: World Bank indicators; OECD PISA data 
Table 5: Distribution of financial literacy score across selected socio-economic characteristics (by country)

\begin{tabular}{lcccccccccccc}
\hline \hline & AT & BR & CA & HR & FI & DE & HK & HU & JO & NL & RU & UK \\
\hline Overall & 4.8 & 4.3 & 4.9 & 4.3 & 5.2 & 4.8 & 5.8 & 4.7 & 4.3 & 4.9 & 4.1 & 4.2 \\
\hline Gender & & & & & & & & & & & & \\
$\quad$ Male & 5.1 & 4.4 & 5.4 & 4.3 & 5.4 & 5.3 & 6.0 & 4.8 & 4.7 & 5.5 & 4.2 & 4.6 \\
$\quad$ Female & 4.5 & 4.2 & 4.5 & 4.2 & 4.9 & 4.3 & 5.6 & 4.6 & 3.8 & 4.3 & 4.1 & 3.8 \\
\hline Education & & & & & & & & & & & & \\
$\quad$ Primary & 3.8 & 3.9 & 3.8 & 3.9 & N.A. & 4.1 & 4.6 & 4.3 & 3.4 & 4.0 & 3.4 & 3.1 \\
$\quad$ Secondary & 4.9 & 4.5 & 4.6 & 4.3 & 5.0 & 5.0 & 5.9 & 4.7 & 3.9 & 4.5 & 4.1 & 4.0 \\
$\quad$ Tertiary & 5.6 & 5.2 & 5.4 & 4.8 & 5.8 & 5.7 & 6.1 & 5.4 & 4.6 & 5.6 & 4.5 & 5.0 \\
\hline Age category & & & & & & & & & & & & \\
$\quad$ 18-29 years & 4.6 & 4.4 & 4.5 & 4.1 & 5.0 & 4.4 & 5.5 & 4.7 & 3.5 & 4.3 & 3.8 & 3.7 \\
30-49 years & 4.8 & 4.4 & 5.0 & 4.4 & 5.4 & 4.7 & 5.9 & 4.8 & 4.1 & 4.9 & 4.2 & 4.6 \\
$\quad$ 50-69 years & 5.0 & 4.2 & 5.1 & 4.4 & 5.2 & 5.0 & 5.8 & 4.7 & 4.6 & 5.2 & 4.3 & 4.4 \\
$\quad$ 70+ years & 4.6 & 4.1 & 4.7 & 3.7 & 4.9 & 4.5 & 5.2 & 4.5 & 4.7 & 5.0 & 4.2 & 3.4 \\
\hline Employment status & & & & & & & & & & & \\
$\quad$ Employed & 4.9 & 4.6 & 5.0 & 4.4 & 5.4 & 5.1 & 6.0 & 4.8 & 4.8 & 5.1 & 4.3 & 4.5 \\
$\quad$ Self-employed & 5.1 & 4.3 & 5.4 & 4.6 & 5.6 & 5.6 & 5.7 & 5.2 & 4.8 & 5.6 & 4.2 & 4.6 \\
$\quad$ Retired & 4.8 & 4.0 & 5.1 & 4.0 & 4.9 & 4.7 & 5.4 & 4.4 & 4.6 & 5.2 & 3.8 & 3.9 \\
$\quad$ Other not working & 4.3 & 4.2 & 4.3 & 4.2 & 5.2 & 4.1 & 5.5 & 4.8 & 3.8 & 4.5 & 4.0 & 3.5 \\
\hline \hline
\end{tabular}

Note: Means are presented based on the sample of adult individuals aged 18-79. Weighted figures except Jordan (JO) and Russia (RU), where survey weights are not available.

Source: OECD/INFE international survey of adult financial literacy competencies 
Table 6: Baseline OLS estimates of determinants of financial literacy

\begin{tabular}{lcc}
\hline \hline & $(1)$ & $(2)$ \\
\hline Income buffer & $0.621^{* * *}$ & $0.439^{* * *}$ \\
Gender & $(0.030)$ & $(0.031)$ \\
& $-0.429^{* * *}$ & $-0.452^{* * *}$ \\
Single & $(0.029)$ & $(0.028)$ \\
& $-0.078^{* *}$ & $-0.131^{* * *}$ \\
University education & $(0.039)$ & $(0.039)$ \\
& $0.543^{* * *}$ & $0.655^{* * *}$ \\
Age category (18-29) & $(0.031)$ & $(0.033)$ \\
& $-0.148^{* *}$ & -0.015 \\
Age category (30-49) & $0.074)$ & $(0.074)$ \\
& $(0.067$ & $0.135^{*}$ \\
Age category (50-69) & $0.247^{* * *}$ & $(0.069)$ \\
& $(0.061)$ & $(0.059)$ \\
Employed & $0.217^{* * *}$ & $0.239^{* * *}$ \\
Self-employed & $(0.042)$ & $(0.041)$ \\
& 0.088 & $0.188^{* * *}$ \\
Retired & $(0.055)$ & $(0.056)$ \\
& -0.048 & 0.023 \\
Constant & $(0.059)$ & $(0.058)$ \\
& $4.507^{* * *}$ & $4.878^{* * *}$ \\
Country fixed effects & $(0.079)$ & $(0.089)$ \\
\hline Adjusted $R^{2}$ & 0.099 & Yes \\
Observations & 12,298 & 0.144 \\
\hline \hline
\end{tabular}

Note: Robust standard errors presented in parentheses. Dummy variables for Age category $(70+)$, Notworking, and Finland are the baseline categories for the respective dummy sets. ${ }^{*} p<0.10,{ }^{* *} p<0.05,{ }^{* * *}$ $p<0.01$.

Source: OECD/INFE international survey of adult financial literacy competencies 
Table 7: Blinder-Oaxaca decomposition at mean (baseline)

\begin{tabular}{|c|c|c|c|c|c|c|c|c|c|c|c|}
\hline & $\mathrm{AT}$ & BR & CA & HR & $\mathrm{DE}$ & HK & $\mathrm{HU}$ & $\mathrm{JO}$ & NL & $\mathrm{RU}$ & UK \\
\hline \multicolumn{12}{|l|}{ I. Differential } \\
\hline Benchmark (Finland) & $\begin{array}{c}5.270^{* * *} \\
(0.042)\end{array}$ & $\begin{array}{c}5.270^{* * *} \\
(0.042)\end{array}$ & $\begin{array}{c}5.270^{* * *} \\
(0.042)\end{array}$ & $\begin{array}{c}5.270^{* * *} \\
(0.042)\end{array}$ & $\begin{array}{c}5.270^{* * *} \\
(0.042)\end{array}$ & $\begin{array}{c}5.270^{* * *} \\
(0.042)\end{array}$ & $\begin{array}{c}5.270^{* * *} \\
(0.042)\end{array}$ & $\begin{array}{c}5.270^{* * *} \\
(0.042)\end{array}$ & $\begin{array}{c}5.270^{* * *} \\
(0.042)\end{array}$ & $\begin{array}{c}5.270^{* * *} \\
(0.042)\end{array}$ & $\begin{array}{c}5.270^{* * *} \\
(0.042)\end{array}$ \\
\hline Compared country & $\begin{array}{c}4.968^{* * *} \\
(0.040)\end{array}$ & $\begin{array}{c}4.510^{* * *} \\
(0.045)\end{array}$ & $\begin{array}{c}4.978^{* * *} \\
(0.044)\end{array}$ & $\begin{array}{c}4.371^{* * *} \\
(0.052)\end{array}$ & $\begin{array}{c}5.247^{* * *} \\
(0.053)\end{array}$ & $\begin{array}{c}5.778^{* * *} \\
(0.040)\end{array}$ & $\begin{array}{c}4.764^{* * *} \\
(0.050)\end{array}$ & $\begin{array}{c}4.483^{* * *} \\
(0.048)\end{array}$ & $\begin{array}{c}5.309^{* * *} \\
(0.055)\end{array}$ & $\begin{array}{c}4.430^{* * *} \\
(0.054)\end{array}$ & $\begin{array}{l}4.602^{* * *} \\
(0.054)\end{array}$ \\
\hline Difference (raw) & $\begin{array}{c}0.302^{* * *} \\
(0.058)\end{array}$ & $\begin{array}{c}0.759^{* * *} \\
(0.061)\end{array}$ & $\begin{array}{c}0.292^{* * *} \\
(0.061)\end{array}$ & $\begin{array}{c}0.899^{* * *} \\
(0.067)\end{array}$ & $\begin{array}{c}0.023 \\
(0.067)\end{array}$ & $\begin{array}{c}-0.509^{* * *} \\
(0.058)\end{array}$ & $\begin{array}{c}0.506^{* * *} \\
(0.065)\end{array}$ & $\begin{array}{c}0.787^{* * *} \\
(0.064)\end{array}$ & $\begin{array}{l}-0.040 \\
(0.069)\end{array}$ & $\begin{array}{c}0.839^{* * *} \\
(0.068)\end{array}$ & $\begin{array}{c}0.667^{* * *} \\
(0.068)\end{array}$ \\
\hline Difference (\%) & $5.9 \%$ & $15.5 \%$ & $5.7 \%$ & $18.6 \%$ & $0.5 \%$ & $-9.2 \%$ & $10.1 \%$ & $16.1 \%$ & $-0.7 \%$ & $17.3 \%$ & 13.5 \\
\hline \multicolumn{12}{|l|}{ II. Decomposition } \\
\hline Explained & $\begin{array}{c}0.179^{* * *} \\
(0.032)\end{array}$ & $\begin{array}{l}0.115^{* *} \\
(0.048)\end{array}$ & $\begin{array}{c}-0.207^{* * *} \\
(0.037)\end{array}$ & $\begin{array}{c}0.161^{* * *} \\
(0.035)\end{array}$ & $\begin{array}{l}-0.036 \\
(0.035)\end{array}$ & $\begin{array}{l}-0.066 \\
(0.046)\end{array}$ & $\begin{array}{c}0.175^{* * *} \\
(0.042)\end{array}$ & $\begin{array}{c}-0.289^{* * *} \\
(0.066)\end{array}$ & $\begin{array}{c}-0.167^{* * *} \\
(0.050)\end{array}$ & $\begin{array}{c}0.094^{* *} \\
(0.048)\end{array}$ & $\begin{array}{c}-0.091^{* * *} \\
(0.033)\end{array}$ \\
\hline Unexplained & $\begin{array}{l}0.123^{*} \\
(0.068)\end{array}$ & $\begin{array}{c}0.644^{* * *} \\
(0.080)\end{array}$ & $\begin{array}{c}0.499^{* * *} \\
(0.069) \\
\end{array}$ & $\begin{array}{c}0.738^{* * *} \\
(0.078) \\
\end{array}$ & $\begin{array}{c}0.059 \\
(0.075) \\
\end{array}$ & $\begin{array}{c}-0.443^{* * *} \\
(0.074) \\
\end{array}$ & $\begin{array}{c}0.331^{* * *} \\
(0.080) \\
\end{array}$ & $\begin{array}{c}1.076^{* * *} \\
(0.091) \\
\end{array}$ & $\begin{array}{c}0.127 \\
(0.084) \\
\end{array}$ & $\begin{array}{c}0.745^{* * *} \\
(0.085) \\
\end{array}$ & $\begin{array}{c}0.758^{* * *} \\
(0.075) \\
\end{array}$ \\
\hline
\end{tabular}

Note: Only basic socio-economic characteristics (i.e. income buffer, gender, age, education, and working status) used as explanatory variables in the underlying regressions. Robust standard errors presented in parentheses. ${ }^{*} p<0.10,{ }^{* *} p<0.05,{ }^{* *} p<0.01$.

Source: OECD/INFE international survey of adult financial literacy competencies 
Table 8: RIF Blinder-Oaxaca quantile decomposition (baseline)

\begin{tabular}{|c|c|c|c|c|c|c|c|c|c|c|c|}
\hline & AT & BR & $\mathrm{CA}$ & HR & $\mathrm{DE}$ & HK & $\mathrm{HU}$ & $\mathrm{JO}$ & NL & $\mathrm{RU}$ & UK \\
\hline & \multicolumn{11}{|c|}{ RIF B-O decomposition for 10 th percentile } \\
\hline \multicolumn{12}{|l|}{ I. Differential } \\
\hline Benchmark (Finland) & $\begin{array}{c}3.407^{* * *} \\
(0.054)\end{array}$ & $\begin{array}{c}3.407^{* * *} \\
(0.054)\end{array}$ & $\begin{array}{c}3.407^{* * *} \\
(0.054)\end{array}$ & $\begin{array}{c}3.407^{* * *} \\
(0.054)\end{array}$ & $\begin{array}{c}3.407^{* * *} \\
(0.054)\end{array}$ & $\begin{array}{c}3.407^{* * *} \\
(0.054)\end{array}$ & $\begin{array}{c}3.407^{* * *} \\
(0.054)\end{array}$ & $\begin{array}{c}3.407^{* * *} \\
(0.054)\end{array}$ & $\begin{array}{c}3.407^{* * *} \\
(0.054)\end{array}$ & $\begin{array}{c}3.407^{* * *} \\
(0.054)\end{array}$ & $\begin{array}{c}3.407^{* * *} \\
(0.054)\end{array}$ \\
\hline Compared country & $\begin{array}{c}2.644^{* * *} \\
(0.062)\end{array}$ & $\begin{array}{c}2.438^{* * *} \\
(0.037)\end{array}$ & $\begin{array}{c}3.308^{* * *} \\
(0.049)\end{array}$ & $\begin{array}{c}2.508^{* * *} \\
(0.067)\end{array}$ & $\begin{array}{c}3.124^{* * *} \\
(0.092)\end{array}$ & $\begin{array}{c}4.203^{* * *} \\
(0.075)\end{array}$ & $\begin{array}{c}2.811^{* * *} \\
(0.070)\end{array}$ & $\begin{array}{c}2.696^{* * *} \\
(0.048)\end{array}$ & $\begin{array}{c}2.837^{* * *} \\
(0.124)\end{array}$ & $\begin{array}{c}2.344^{* * *} \\
(0.058)\end{array}$ & $\begin{array}{c}2.356^{* * *} \\
(0.091)\end{array}$ \\
\hline Difference (raw) & $\begin{array}{c}0.763^{* * *} \\
(0.082)\end{array}$ & $\begin{array}{c}0.969^{* * *} \\
(0.066)\end{array}$ & $\begin{array}{c}0.099 \\
(0.074)\end{array}$ & $\begin{array}{c}0.899^{* * *} \\
(0.086)\end{array}$ & $\begin{array}{c}0.283^{* * *} \\
(0.107)\end{array}$ & $\begin{array}{c}-0.796^{* * *} \\
(0.093)\end{array}$ & $\begin{array}{c}0.595^{* * *} \\
(0.089)\end{array}$ & $\begin{array}{c}0.711^{* * *} \\
(0.072)\end{array}$ & $\begin{array}{c}0.570^{* * *} \\
(0.135)\end{array}$ & $\begin{array}{c}1.063^{* * *} \\
(0.080)\end{array}$ & $\begin{array}{r}1.051^{* * *} \\
(0.106)\end{array}$ \\
\hline Difference $(\%)$ & $25.2 \%$ & $33.2 \%$ & $2.9 \%$ & $30.4 \%$ & $8.7 \%$ & $-20.9 \%$ & $19.2 \%$ & $20.3 \%$ & $18.3 \%$ & $37.0 \%$ & $36.5 \%$ \\
\hline \multicolumn{12}{|l|}{ II. Decomposition } \\
\hline Explained & $\begin{array}{l}0.075^{*} \\
(0.040)\end{array}$ & $\begin{array}{l}0.093^{*} \\
(0.052)\end{array}$ & $\begin{array}{c}-0.098^{* *} \\
(0.046)\end{array}$ & $\begin{array}{c}0.084^{* *} \\
(0.042)\end{array}$ & $\begin{array}{l}-0.054 \\
(0.044)\end{array}$ & $\begin{array}{c}-0.052 \\
(0.058)\end{array}$ & $\begin{array}{c}0.103^{* *} \\
(0.050)\end{array}$ & $\begin{array}{l}-0.022 \\
(0.086)\end{array}$ & $\begin{array}{c}-0.109^{*} \\
(0.065)\end{array}$ & $\begin{array}{c}0.141^{* *} \\
(0.060)\end{array}$ & $\begin{array}{l}-0.030 \\
(0.041)\end{array}$ \\
\hline Unexplained & $\begin{array}{c}0.688^{* * *} \\
(0.097)\end{array}$ & $\begin{array}{c}0.877^{* * *} \\
(0.091)\end{array}$ & $\begin{array}{c}0.197^{* *} \\
(0.079)\end{array}$ & $\begin{array}{c}0.815^{* * *} \\
(0.102)\end{array}$ & $\begin{array}{c}0.337^{* * *} \\
(0.113)\end{array}$ & $\begin{array}{c}-0.744^{* * *} \\
(0.107) \\
\end{array}$ & $\begin{array}{c}0.492^{* * *} \\
(0.109)\end{array}$ & $\begin{array}{c}0.733^{* * *} \\
(0.111)\end{array}$ & $\begin{array}{c}0.679^{* * *} \\
(0.145)\end{array}$ & $\begin{array}{c}0.922^{* * *} \\
(0.109)\end{array}$ & $\begin{array}{r}1.081^{* * *} \\
(0.112)\end{array}$ \\
\hline & \multicolumn{11}{|c|}{ RIF B-O decomposition for 50th percentile } \\
\hline \multicolumn{12}{|l|}{ I. Differential } \\
\hline Benchmark (Finland) & $\begin{array}{c}6.035^{* * *} \\
(0.045)\end{array}$ & $\begin{array}{c}6.035^{* * *} \\
(0.045)\end{array}$ & $\begin{array}{c}6.035^{* * *} \\
(0.045)\end{array}$ & $\begin{array}{c}6.035^{* * *} \\
(0.045)\end{array}$ & $\begin{array}{c}6.035^{* * *} \\
(0.045)\end{array}$ & $\begin{array}{c}6.035^{* * *} \\
(0.045)\end{array}$ & $\begin{array}{c}6.035^{* * *} \\
(0.045)\end{array}$ & $\begin{array}{c}6.035^{* * *} \\
(0.045)\end{array}$ & $\begin{array}{c}6.035^{* * *} \\
(0.045)\end{array}$ & $\begin{array}{c}6.035^{* * *} \\
(0.045)\end{array}$ & $\begin{array}{c}6.035^{* * *} \\
(0.045)\end{array}$ \\
\hline Compared country & $\begin{array}{c}5.520^{* * *} \\
(0.031)\end{array}$ & $\begin{array}{c}4.840^{* * *} \\
(0.041)\end{array}$ & $\begin{array}{c}5.425^{* * *} \\
(0.055)\end{array}$ & $\begin{array}{c}4.782^{* * *} \\
(0.064)\end{array}$ & $\begin{array}{c}6.100^{* * *} \\
(0.078)\end{array}$ & $\begin{array}{c}6.422^{* * *} \\
(0.035)\end{array}$ & $\begin{array}{c}5.343^{* * *} \\
(0.052)\end{array}$ & $\begin{array}{c}4.825^{* * *} \\
(0.051)\end{array}$ & $\begin{array}{c}6.333^{* * *} \\
(0.074)\end{array}$ & $\begin{array}{c}4.999^{* * *} \\
(0.067)\end{array}$ & $\begin{array}{c}5.317^{* * *} \\
(0.084)\end{array}$ \\
\hline Difference (raw) & $\begin{array}{c}0.515^{* * *} \\
(0.054)\end{array}$ & $\begin{array}{c}1.195^{* * *} \\
(0.061)\end{array}$ & $\begin{array}{c}0.610^{* * *} \\
(0.071)\end{array}$ & $\begin{array}{c}1.253^{* * *} \\
(0.079)\end{array}$ & $\begin{array}{l}-0.065 \\
(0.090)\end{array}$ & $\begin{array}{c}-0.387^{* * *} \\
(0.057)\end{array}$ & $\begin{array}{c}0.692^{* * *} \\
(0.069)\end{array}$ & $\begin{array}{c}1.210^{* * *} \\
(0.068)\end{array}$ & $\begin{array}{c}-0.298^{* * *} \\
(0.087)\end{array}$ & $\begin{array}{c}1.036^{* * *} \\
(0.081)\end{array}$ & $\begin{array}{c}0.718^{* * *} \\
(0.095)\end{array}$ \\
\hline Difference $(\%)$ & $8.9 \%$ & $22.0 \%$ & $10.6 \%$ & $23.2 \%$ & $-1.1 \%$ & $-6.2 \%$ & $12.2 \%$ & $22.3 \%$ & $-4.8 \%$ & $18.8 \%$ & $12.6 \%$ \\
\hline \multicolumn{12}{|l|}{ II. Decomposition } \\
\hline Explained & $\begin{array}{c}0.172^{* * *} \\
(0.035)\end{array}$ & $\begin{array}{l}0.097^{*} \\
(0.053)\end{array}$ & $\begin{array}{c}-0.175^{* * *} \\
(0.038)\end{array}$ & $\begin{array}{c}0.138^{* * *} \\
(0.038)\end{array}$ & $\begin{array}{c}0.003 \\
(0.037)\end{array}$ & $\begin{array}{c}-0.039 \\
(0.048)\end{array}$ & $\begin{array}{c}0.154^{* * *} \\
(0.044)\end{array}$ & $\begin{array}{c}-0.337^{* * *} \\
(0.070)\end{array}$ & $\begin{array}{c}-0.144^{* * *} \\
(0.051)\end{array}$ & $\begin{array}{c}0.045 \\
(0.051)\end{array}$ & $\begin{array}{c}-0.078^{* *} \\
(0.034)\end{array}$ \\
\hline Unexplained & $\begin{array}{c}0.343^{* * *} \\
(0.066) \\
\end{array}$ & $\begin{array}{c}1.097^{* * *} \\
(0.082) \\
\end{array}$ & $\begin{array}{c}0.785^{* * *} \\
(0.079) \\
\end{array}$ & $\begin{array}{c}1.114^{* * *} \\
(0.088) \\
\end{array}$ & $\begin{array}{l}-0.068 \\
(0.097) \\
\end{array}$ & $\begin{array}{c}-0.348^{* * *} \\
(0.074) \\
\end{array}$ & $\begin{array}{c}0.538^{* * *} \\
(0.083) \\
\end{array}$ & $\begin{array}{c}1.547^{* * *} \\
(0.096) \\
\end{array}$ & $\begin{array}{l}-0.154 \\
(0.101) \\
\end{array}$ & $\begin{array}{c}0.991^{* * *} \\
(0.095) \\
\end{array}$ & $\begin{array}{c}0.796^{* * *} \\
(0.101) \\
\end{array}$ \\
\hline & \multicolumn{11}{|c|}{ RIF B-O decomposition for 90th percentile } \\
\hline \multicolumn{12}{|l|}{ I. Differential } \\
\hline Benchmark (Finland) & $\begin{array}{c}7.486^{* * *} \\
(0.039)\end{array}$ & $\begin{array}{c}7.486^{* * *} \\
(0.039)\end{array}$ & $\begin{array}{c}7.486^{* * *} \\
(0.039)\end{array}$ & $\begin{array}{c}7.486^{* * *} \\
(0.039)\end{array}$ & $\begin{array}{c}7.486^{* * *} \\
(0.039)\end{array}$ & $\begin{array}{c}7.486^{* * *} \\
(0.039)\end{array}$ & $\begin{array}{c}7.486^{* * *} \\
(0.039)\end{array}$ & $\begin{array}{c}7.486^{* * *} \\
(0.039)\end{array}$ & $\begin{array}{c}7.486^{* * *} \\
(0.039)\end{array}$ & $\begin{array}{c}7.486^{* * *} \\
(0.039)\end{array}$ & $\begin{array}{r}7.486^{* * *} \\
(0.039)\end{array}$ \\
\hline Compared country & $\begin{array}{c}7.393^{* * *} \\
(0.036)\end{array}$ & $\begin{array}{c}6.825^{* * *} \\
(0.061)\end{array}$ & $\begin{array}{c}7.447^{* * *} \\
(0.050)\end{array}$ & $\begin{array}{c}7.038^{* * *} \\
(0.088)\end{array}$ & $\begin{array}{c}7.731^{* * *} \\
(0.049)\end{array}$ & $\begin{array}{c}7.549^{* * *} \\
(0.031)\end{array}$ & $\begin{array}{c}7.249^{* * *} \\
(0.065)\end{array}$ & $\begin{array}{c}6.883^{* * *} \\
(0.076)\end{array}$ & $\begin{array}{c}7.889^{* * *} \\
(0.050)\end{array}$ & $\begin{array}{c}7.050^{* * *} \\
(0.081)\end{array}$ & $\begin{array}{c}7.452^{* * *} \\
(0.073)\end{array}$ \\
\hline Difference (raw) & $\begin{array}{l}0.093^{*} \\
(0.053)\end{array}$ & $\begin{array}{c}0.660^{* * *} \\
(0.072)\end{array}$ & $\begin{array}{c}0.038 \\
(0.064)\end{array}$ & $\begin{array}{c}0.448^{* * *} \\
(0.097)\end{array}$ & $\begin{array}{c}-0.245^{* * *} \\
(0.062)\end{array}$ & $\begin{array}{c}-0.063 \\
(0.050)\end{array}$ & $\begin{array}{c}0.237^{* * *} \\
(0.076)\end{array}$ & $\begin{array}{c}0.602^{* * *} \\
(0.086)\end{array}$ & $\begin{array}{c}-0.403^{* * *} \\
(0.064)\end{array}$ & $\begin{array}{c}0.435^{* * *} \\
(0.090)\end{array}$ & $\begin{array}{c}0.033 \\
(0.083)\end{array}$ \\
\hline Difference (\%) & $1.3 \%$ & $9.2 \%$ & $0.5 \%$ & $6.2 \%$ & $-3.2 \%$ & $-0.8 \%$ & $3.2 \%$ & $8.4 \%$ & $-5.2 \%$ & $6.0 \%$ & $0.5 \%$ \\
\hline \multicolumn{12}{|l|}{ II. Decomposition } \\
\hline Explained & $\begin{array}{c}0.176^{* * *} \\
(0.033)\end{array}$ & $\begin{array}{c}0.063 \\
(0.047)\end{array}$ & $\begin{array}{c}-0.158^{* * *} \\
(0.036)\end{array}$ & $\begin{array}{c}0.116^{* * *} \\
(0.034)\end{array}$ & $\begin{array}{c}0.012 \\
(0.033)\end{array}$ & $\begin{array}{c}-0.048 \\
(0.043)\end{array}$ & $\begin{array}{c}0.131^{* * *} \\
(0.040)\end{array}$ & $\begin{array}{c}-0.323^{* * *} \\
(0.060)\end{array}$ & $\begin{array}{c}-0.118^{* *} \\
(0.047)\end{array}$ & $\begin{array}{c}0.019 \\
(0.044)\end{array}$ & $\begin{array}{c}-0.065^{* *} \\
(0.032)\end{array}$ \\
\hline Unexplained & $\begin{array}{l}-0.083 \\
(0.060) \\
\end{array}$ & $\begin{array}{c}0.598^{* * *} \\
(0.086)\end{array}$ & $\begin{array}{c}0.197^{* * *} \\
(0.076) \\
\end{array}$ & $\begin{array}{c}0.332^{* * *} \\
(0.101)\end{array}$ & $\begin{array}{c}-0.257^{* * *} \\
(0.071) \\
\end{array}$ & $\begin{array}{l}-0.015 \\
(0.067)\end{array}$ & $\begin{array}{c}0.106 \\
(0.085) \\
\end{array}$ & $\begin{array}{c}0.926^{* * *} \\
(0.107) \\
\end{array}$ & $\begin{array}{c}-0.285^{* * *} \\
(0.081) \\
\end{array}$ & $\begin{array}{c}0.416^{* * *} \\
(0.100)\end{array}$ & $\begin{array}{c}0.099 \\
(0.090) \\
\end{array}$ \\
\hline
\end{tabular}

Note: Only basic socio-economic characteristics (i.e. income buffer, gender, age, education, and working status) used as explanatory variables in the

underlying regressions. Robust standard errors presented in parentheses. ${ }^{*} p<0.10,{ }^{* *} p<0.05,{ }^{* *} p<0.01$.

Source: OECD/INFE international survey of adult financial literacy competencies 
Table 9: Which institutions matter the most? (baseline)

\begin{tabular}{|c|c|c|c|c|c|c|}
\hline \multirow[b]{2}{*}{ Indicator } & \multicolumn{2}{|l|}{ Mean } & \multicolumn{2}{|c|}{ 10th percentile } & \multicolumn{2}{|c|}{ 90th percentile } \\
\hline & Standardized effect & Rank & Standardized effect & Rank & Standardized effect & Rank \\
\hline GDP per capita & $-0.289^{* *}$ & 6 & -0.222 & 5 & $-0.288^{* * *}$ & 4 \\
\hline Gross enrolment ratio & $-0.293^{* * *}$ & 5 & $-0.292^{*}$ & 3 & $-0.233^{\star *}$ & 6 \\
\hline Internet users & $-0.297^{* * *}$ & 4 & -0.200 & 6 & $-0.338^{* * *}$ & 2 \\
\hline Life expectancy & $-0.514^{* *}$ & 1 & $-0.489^{*}$ & 1 & $-0.440^{* *}$ & 1 \\
\hline Math score in PISA & $-0.301^{* * *}$ & 3 & $-0.273^{*}$ & 4 & $-0.283^{* * *}$ & 5 \\
\hline Social contributions rate & $-0.301^{* * *}$ & 2 & $-0.121^{\star}$ & 7 & $-0.307^{* * *}$ & 3 \\
\hline Stock market capitalization & $-0.247^{* * *}$ & 7 & $-0.368^{* * *}$ & 2 & -0.078 & 7 \\
\hline
\end{tabular}

Note: Country-level regressions of the unexplained parts of the gap (coefficient effects) estimated from the mean and quantile decomposition analysis on a set of aggregate indicators (one by one) which have been standardized (i.e. values demeaned and divided by their standard deviations). ${ }^{*} p<0.10,{ }^{* *} p<0.05,{ }^{* * *}$ $p<0.01$.

Source: OECD/INFE international survey of adult financial literacy competencies; World Bank data 


\section{Appendix}

\section{A Financial literacy questions in the OECD/INFE survey}

Below we provide the list of financial literacy knowledge questions (KQ) asked in the OECD/INFE survey on financial literacy of adult individuals that were used for the calculation of the overall financial knowledge score. For sake of space-saving, answer options such as "Don't know" or "Refused to answer" are omitted.

- KQ1 Time-value of money: Imagine that five brothers are given a gift of EUR 1,000 and have to share the money equally. The brothers have to wait for one year to get their share of the EUR 1,000 and inflation stays at 2\%. In one year's time, will they be able to buy (a) more with their share of the money than they could today, (b) as much as today, or (c) less than they could buy today? (correct answer: c)

- KQ2 Interest paid on a loan: You lend EUR 25 to a friend one evening and he gives you EUR 25 back the next day. How much interest has he paid on this loan? (correct answer: 0$)$

- KQ3 Interest plus principal: Suppose you put EUR 100 into a no-fee savings account with a guaranteed interest rate of $2 \%$ per year. You do not make any further payments into this account and you do not withdraw any money. How much would be in the account at the end of the first year, once the interest payment is made? (correct answer: 102 EUR)

- KQ4 Compound interest: And how much would be in the account at the end of five years? (a) More than EUR 110, (b) exactly EUR 110, (c) less than EUR 110, (d) It is impossible to tell from the information given. (correct answer: a)

- KQ5 Risk and return: Is the following statement (a) true or (b) false? An investment with a high return is likely to be high risk. (correct answer: a)

- KQ6 Definition of inflation: Is the following statement (a) true or (b) false? High inflation means that the cost of living is increasing rapidly. (correct answer: a)

- KQ7 Diversification: Is the following statement (a) true or (b) false? It is usually possible to reduce the risk of investing in the stock market by buying a wide range of stocks and shares. (correct answer: a) 


\section{B The importance of experience for financial literacy}

As a robustness check, we extend our multivariate and decomposition analysis by considering a set of variables capturing experience with finance (see Table 2, for exact definition). The inclusion of these endogenous variables to better explain financial literacy gaps across countries is justified by the prior literature studying the reverse causality between financial knowledge and financial outcomes of households and individuals (e.g. Fernandes et al., 2014).

\section{B.1 Production function}

The results on experience variables (presented in Table B.1) are remarkable in two dimensions. First, with regard to having a budget. This dummy variable indicates whether an individual is responsible for the budget, if the household has a budget at all and is used by the OECD in their so called "financial behavior" score. However, it interestingly relates to marginally lower financial literacy. This could be for two reasons. Either low-income, low-educated households have a higher probability of having a budget as they have more need to do so. If so, it might not be a good indicator for using it in a "financial behavior" score as it only captures a selection issue and is a proxy for tight finances. Or the less financially literate person in a household typically is responsible for the households budget. That would be worrisome as it would lead to less efficient budgeting. In both cases it questions the definition and use in the OECD's "financial behavior score" in this combination of two variables, a household having a budget and a person being responsible for that budget. Second all other experience variables are associated with higher financial literacy. In particular, holding risky financial assets and financial planning also have economically significant effects of about 0.2 (financial planning) and 0.3 to 0.4 (holding risky assets). Of course these coefficients should not be interpreted as causal effects but rather as predictive effects or conditional correlations. We consider it likely that individuals learn before and while they are dealing with certain financial products how to deal with such products and thereby increase their financial knowledge which is partly covered by our observed financial literacy scores. 
Table B.1: OLS estimates of determinants of financial literacy (robustness check)

\begin{tabular}{|c|c|c|c|c|}
\hline & (1) & $(2)$ & $(3)$ & $(4)$ \\
\hline Income buffer & $\begin{array}{c}0.621^{* * *} \\
(0.030)\end{array}$ & $\begin{array}{c}0.439^{* * *} \\
(0.031)\end{array}$ & $\begin{array}{c}0.473^{* * *} \\
(0.033)\end{array}$ & $\begin{array}{c}0.306^{* * *} \\
(0.034)\end{array}$ \\
\hline Gender & $\begin{array}{c}-0.429^{* * *} \\
(0.029)\end{array}$ & $\begin{array}{c}-0.452^{* * *} \\
(0.028)\end{array}$ & $\begin{array}{c}-0.387^{* * *} \\
(0.030)\end{array}$ & $\begin{array}{c}-0.419^{* * *} \\
(0.029)\end{array}$ \\
\hline Single & $\begin{array}{c}-0.078^{* *} \\
(0.039)\end{array}$ & $\begin{array}{c}-0.131^{* * *} \\
(0.039)\end{array}$ & $\begin{array}{l}-0.023 \\
(0.040)\end{array}$ & $\begin{array}{c}-0.094^{* *} \\
(0.040)\end{array}$ \\
\hline University education & $\begin{array}{c}0.543^{* * *} \\
(0.031)\end{array}$ & $\begin{array}{c}0.655^{* * *} \\
(0.033)\end{array}$ & $\begin{array}{c}0.452^{* * *} \\
(0.032)\end{array}$ & $\begin{array}{c}0.568^{* * *} \\
(0.033)\end{array}$ \\
\hline Age category (18-29) & $\begin{array}{c}-0.148^{* *} \\
(0.074)\end{array}$ & $\begin{array}{l}-0.015 \\
(0.074)\end{array}$ & $\begin{array}{c}-0.236^{* * *} \\
(0.077)\end{array}$ & $\begin{array}{l}-0.056 \\
(0.076)\end{array}$ \\
\hline Age category (30-49) & $\begin{array}{c}0.067 \\
(0.070)\end{array}$ & $\begin{array}{c}0.135^{*} \\
(0.069)\end{array}$ & $\begin{array}{l}-0.059 \\
(0.073)\end{array}$ & $\begin{array}{c}0.044 \\
(0.072)\end{array}$ \\
\hline Age category (50-69) & $\begin{array}{c}0.247^{* * *} \\
(0.061)\end{array}$ & $\begin{array}{c}0.288^{* * *} \\
(0.059)\end{array}$ & $\begin{array}{c}0.092 \\
(0.063)\end{array}$ & $\begin{array}{l}0.156^{* *} \\
(0.062)\end{array}$ \\
\hline Employed & $\begin{array}{c}0.217^{* * *} \\
(0.042)\end{array}$ & $\begin{array}{c}0.239^{* * *} \\
(0.041)\end{array}$ & $\begin{array}{c}0.133^{* * *} \\
(0.043)\end{array}$ & $\begin{array}{c}0.142^{* * *} \\
(0.042)\end{array}$ \\
\hline Self-employed & $\begin{array}{c}0.088 \\
(0.055)\end{array}$ & $\begin{array}{c}0.188^{* * *} \\
(0.056)\end{array}$ & $\begin{array}{l}-0.043 \\
(0.055)\end{array}$ & $\begin{array}{c}0.087 \\
(0.056)\end{array}$ \\
\hline Retired & $\begin{array}{l}-0.048 \\
(0.059)\end{array}$ & $\begin{array}{c}0.023 \\
(0.058)\end{array}$ & $\begin{array}{l}-0.116^{*} \\
(0.060)\end{array}$ & $\begin{array}{l}-0.045 \\
(0.060)\end{array}$ \\
\hline Having budget & & & $\begin{array}{c}-0.066^{* *} \\
(0.030)\end{array}$ & $\begin{array}{l}-0.005 \\
(0.031)\end{array}$ \\
\hline Active saver & & & $\begin{array}{l}0.080^{* *} \\
(0.033)\end{array}$ & $\begin{array}{l}0.072^{* *} \\
(0.033)\end{array}$ \\
\hline Holding risky financial assets & & & $\begin{array}{c}0.392^{* * *} \\
(0.037)\end{array}$ & $\begin{array}{c}0.293^{* * *} \\
(0.038)\end{array}$ \\
\hline Financial planning & & & $\begin{array}{c}0.213^{* * *} \\
(0.031)\end{array}$ & $\begin{array}{c}0.174^{* * *} \\
(0.031)\end{array}$ \\
\hline Constant & $\begin{array}{c}4.507^{* * *} \\
(0.079)\end{array}$ & $\begin{array}{c}4.878^{* * *} \\
(0.089)\end{array}$ & $\begin{array}{c}4.662^{* * *} \\
(0.084)\end{array}$ & $\begin{array}{c}4.853^{* * *} \\
(0.094)\end{array}$ \\
\hline Country fixed effects & No & Yes & No & Yes \\
\hline Adjusted $R^{2}$ & 0.099 & 0.144 & 0.107 & 0.148 \\
\hline Observations & 12,298 & 12,298 & 10,810 & 10,810 \\
\hline
\end{tabular}

Note: Robust standard errors presented in parentheses. Dummy variables for Age category $(70+)$, Notworking, and Finland are the baseline categories for the respective dummy sets. ${ }^{*} p<0.10,{ }^{* *} p<0.05,{ }^{* *}$ $p<0.01$.

Source: OECD/INFE international survey of adult financial literacy competencies

\section{B.2 Decomposition}

One might ask to what degree learning-by-doing which we capture by experience might further explain the observed gaps between countries. We investigate this by adding the experience covariates to our decomposition analysis.

The results of this part are summarized in Table B.2. In Canada, Jordan, The Netherlands and the UK individual characteristics and experience still dampen the observed differences, 
while for Austria, Brazil, Croatia, Hungary and Russia the gap appears still larger. The robustness of these results points towards the fact that different missing patterns of individual characteristics and experiences do not distort our analysis. Once experience is added the gap is closed for Austria and almost closed (96\% explained) for Hungary. It also reduces strongly for Brazil (from 15\% to $32 \%$ explained) and Russia (from $11 \%$ to $23 \%$ explained), while it stays almost the same for Croatia (about 18\% explained). Canada is driven even further away, meaning that when comparing now individuals with similar "experience" and characteristics in Canada and Finland, the within group gap to Finland is even larger. The same, but to a lesser degree is true for the UK. The Netherlands and Jordan almost stay the same. In Germany the slightly higher scores (in this setting) are fully explained by experience and also in Hong Kong about $28 \%$ are explained by experience.

All in all, we can see that experience matters in the case of financial literacy. With our observational framework, we can not clearly identify the causal pathway: Does experience lead people to learn more about financial products or do they learn more and then decide to apply the things they learned by changing their investment behavior? However, it is important to know that some of the differences between countries are explainable by varying experience of individuals with financial products. One reason could be different welfare state regimes. In some countries (e.g. Brazil, Russia or the UK) investing privately for old age provision or other precautionary motives is more important than in other countries (e.g. Austria, Finland or Germany). Also supply is different in different countries. In some countries, intermediation of banks is stronger (continental Europe) than in others (e.g. the UK). All of these might induce more experience and therefore change financial literacy as well as the need for financial literacy. We discuss in more detail the importance of institutions in subsection 4.4.

Note that experience might matter more for sophisticated than for basic financial literacy. That is why we engage in a decomposition exercise at different points of the distribution of financial literacy. 
Table B.2: B-O decomposition at mean (robustness check)

\begin{tabular}{|c|c|c|c|c|c|c|c|c|c|c|c|}
\hline & $\mathrm{AT}$ & BR & $\mathrm{CA}$ & HR & $\mathrm{DE}$ & HK & $\mathrm{HU}$ & $\mathrm{JO}$ & NL & $\mathrm{RU}$ & UK \\
\hline \multicolumn{12}{|l|}{ I. Differential } \\
\hline Benchmark (Finland) & $\begin{array}{c}5.282^{* * *} \\
(0.041)\end{array}$ & $\begin{array}{c}5.282^{* * *} \\
(0.041)\end{array}$ & $\begin{array}{c}5.282^{* * *} \\
(0.041)\end{array}$ & $\begin{array}{c}5.282^{* * *} \\
(0.041)\end{array}$ & $\begin{array}{c}5.282^{* * *} \\
(0.041)\end{array}$ & $\begin{array}{c}5.282^{* * *} \\
(0.041)\end{array}$ & $\begin{array}{c}5.282^{* * *} \\
(0.041)\end{array}$ & $\begin{array}{c}5.282^{* * *} \\
(0.041)\end{array}$ & $\begin{array}{c}5.282^{* * *} \\
(0.041)\end{array}$ & $\begin{array}{c}5.282^{* * *} \\
(0.041)\end{array}$ & $\begin{array}{c}5.282^{* * *} \\
(0.041)\end{array}$ \\
\hline Compared country & $\begin{array}{c}5.246^{* * *} \\
(0.040)\end{array}$ & $\begin{array}{c}4.510^{* * *} \\
(0.044)\end{array}$ & $\begin{array}{c}5.273^{* * *} \\
(0.047)\end{array}$ & $\begin{array}{c}4.545^{* * *} \\
(0.055)\end{array}$ & $\begin{array}{c}5.473^{* * *} \\
(0.053)\end{array}$ & $\begin{array}{c}5.778^{* * *} \\
(0.039)\end{array}$ & $\begin{array}{c}4.993^{* * *} \\
(0.055)\end{array}$ & $\begin{array}{c}4.603^{* * *} \\
(0.049)\end{array}$ & $\begin{array}{c}5.309^{* * *} \\
(0.054)\end{array}$ & $\begin{array}{c}4.437^{* * *} \\
(0.053)\end{array}$ & $\begin{array}{l}4.915^{* * *} \\
(0.057)\end{array}$ \\
\hline Difference (raw) & $\begin{array}{c}0.036 \\
(0.058)\end{array}$ & $\begin{array}{c}0.772^{* * *} \\
(0.061)\end{array}$ & $\begin{array}{c}0.010 \\
(0.063)\end{array}$ & $\begin{array}{c}0.737^{* * *} \\
(0.069)\end{array}$ & $\begin{array}{c}-0.191^{* * *} \\
(0.067)\end{array}$ & $\begin{array}{c}-0.496^{* * *} \\
(0.057)\end{array}$ & $\begin{array}{c}0.289^{* * *} \\
(0.069)\end{array}$ & $\begin{array}{c}0.679^{* * *} \\
(0.064)\end{array}$ & $\begin{array}{l}-0.027 \\
(0.068)\end{array}$ & $\begin{array}{c}0.846^{* * *} \\
(0.067)\end{array}$ & $\begin{array}{c}0.367^{* * *} \\
(0.071)\end{array}$ \\
\hline Difference (\%) & $0.7 \%$ & $15.8 \%$ & $0.2 \%$ & $15.0 \%$ & $-3.6 \%$ & $-9.0 \%$ & $5.6 \%$ & $13.7 \%$ & $-0.5 \%$ & $17.4 \%$ & $7.2 \%$ \\
\hline \multicolumn{12}{|l|}{ II. Decomposition } \\
\hline Explained & $\begin{array}{c}0.123^{* * *} \\
(0.047)\end{array}$ & $\begin{array}{c}0.246^{* * *} \\
(0.057)\end{array}$ & $\begin{array}{c}-0.365^{* * *} \\
(0.046)\end{array}$ & $\begin{array}{c}0.134^{* * *} \\
(0.044)\end{array}$ & $\begin{array}{c}-0.131^{* * *} \\
(0.047)\end{array}$ & $\begin{array}{c}-0.141^{* * *} \\
(0.049)\end{array}$ & $\begin{array}{c}0.278^{* * *} \\
(0.057)\end{array}$ & $\begin{array}{c}-0.264^{* * *} \\
(0.067)\end{array}$ & $\begin{array}{c}-0.145^{* *} \\
(0.061)\end{array}$ & $\begin{array}{c}0.191^{* * *} \\
(0.054)\end{array}$ & $\begin{array}{c}-0.203^{* * *} \\
(0.047)\end{array}$ \\
\hline Unexplained & $\begin{array}{l}-0.087 \\
(0.076)\end{array}$ & $\begin{array}{c}0.525^{* * *} \\
(0.086)\end{array}$ & $\begin{array}{c}0.375^{* * *} \\
(0.073) \\
\end{array}$ & $\begin{array}{c}0.604^{* * *} \\
(0.083) \\
\end{array}$ & $\begin{array}{l}-0.060 \\
(0.080) \\
\end{array}$ & $\begin{array}{c}-0.355^{* * *} \\
(0.073) \\
\end{array}$ & $\begin{array}{c}0.011 \\
(0.092) \\
\end{array}$ & $\begin{array}{c}0.943^{* * *} \\
(0.092) \\
\end{array}$ & $\begin{array}{c}0.117 \\
(0.090) \\
\end{array}$ & $\begin{array}{c}0.655^{* * *} \\
(0.089) \\
\end{array}$ & $\begin{array}{c}0.569^{* * *} \\
(0.082) \\
\end{array}$ \\
\hline
\end{tabular}

Note: In addition to basic socio-economic characteristics, variables capturing experience with finance (i.e. having budget, having savings products, holding risky financial assets, and engaging in financial planning) are considered in the underlying regressions. Robust standard errors presented in parentheses. ${ }^{*} p<0.10,{ }^{* *} p<0.05,{ }^{* * *} p<0.01$. 
Table B.3: RIF B-O quantile decomposition (robustness check)

\begin{tabular}{|c|c|c|c|c|c|c|c|c|c|c|c|}
\hline & $\mathrm{AT}$ & BR & $\mathrm{CA}$ & HR & DE & HK & $\mathrm{HU}$ & $\mathrm{JO}$ & NL & $\mathrm{RU}$ & UK \\
\hline & \multicolumn{11}{|c|}{ RIF B-O decomposition for 10th Percentile } \\
\hline \multirow{2}{*}{$\begin{array}{l}\text { I. Differential } \\
\text { Benchmark (Finland) }\end{array}$} & & & & & & & & & & & \\
\hline & $\begin{array}{c}3.430^{* * *} \\
(0.053)\end{array}$ & $\begin{array}{c}3.430^{* * *} \\
(0.053)\end{array}$ & $\begin{array}{c}3.430^{* * *} \\
(0.053)\end{array}$ & $\begin{array}{c}3.430^{* * *} \\
(0.053)\end{array}$ & $\begin{array}{c}3.430^{* * *} \\
(0.053)\end{array}$ & $\begin{array}{c}3.430^{* * *} \\
(0.053)\end{array}$ & $\begin{array}{c}3.430^{* * *} \\
(0.053)\end{array}$ & $\begin{array}{c}3.430^{* * *} \\
(0.053)\end{array}$ & $\begin{array}{c}3.430^{* * *} \\
(0.053)\end{array}$ & $\begin{array}{c}3.430^{* * *} \\
(0.053)\end{array}$ & $\begin{array}{c}3.430^{* * *} \\
(0.053)\end{array}$ \\
\hline Compared country & $\begin{array}{c}2.902^{* * *} \\
(0.053)\end{array}$ & $\begin{array}{c}2.438^{* * *} \\
(0.037)\end{array}$ & $\begin{array}{c}3.499^{* * *} \\
(0.040)\end{array}$ & $\begin{array}{c}2.641^{* * *} \\
(0.062)\end{array}$ & $\begin{array}{c}3.363^{* * *} \\
(0.074)\end{array}$ & $\begin{array}{c}4.203^{* * *} \\
(0.075)\end{array}$ & $\begin{array}{c}2.931^{* * *} \\
(0.068)\end{array}$ & $\begin{array}{c}2.791^{* * *} \\
(0.039)\end{array}$ & $\begin{array}{c}2.837^{* * *} \\
(0.123)\end{array}$ & $\begin{array}{c}2.362^{* * *} \\
(0.057)\end{array}$ & $\begin{array}{c}2.681^{* * *} \\
(0.081)\end{array}$ \\
\hline Difference (raw) & $\begin{array}{c}0.528^{* * *} \\
(0.075)\end{array}$ & $\begin{array}{c}0.992^{* * *} \\
(0.065)\end{array}$ & $\begin{array}{l}-0.069 \\
(0.067)\end{array}$ & $\begin{array}{c}0.789^{* * *} \\
(0.082)\end{array}$ & $\begin{array}{c}0.066 \\
(0.091)\end{array}$ & $\begin{array}{c}-0.773^{* * *} \\
(0.092)\end{array}$ & $\begin{array}{c}0.498^{* * *} \\
(0.086)\end{array}$ & $\begin{array}{c}0.639^{* * *} \\
(0.066)\end{array}$ & $\begin{array}{c}0.593^{* * *} \\
(0.134)\end{array}$ & $\begin{array}{c}1.068^{* * *} \\
(0.078)\end{array}$ & $\begin{array}{c}0.749^{* * *} \\
(0.097)\end{array}$ \\
\hline Difference (\%) & $16.7 \%$ & $33.8 \%$ & $-2.0 \%$ & $26.0 \%$ & $2.0 \%$ & $-20.3 \%$ & $15.7 \%$ & $20.5 \%$ & $18.9 \%$ & $36.9 \%$ & $24.5 \%$ \\
\hline \multicolumn{12}{|l|}{ II. Decomposition } \\
\hline Explained & $\begin{array}{c}0.028 \\
(0.062)\end{array}$ & $\begin{array}{c}0.172^{* * *} \\
(0.066)\end{array}$ & $\begin{array}{c}-0.189^{* * *} \\
(0.060)\end{array}$ & $\begin{array}{c}0.055 \\
(0.055)\end{array}$ & $\begin{array}{l}-0.102 \\
(0.063)\end{array}$ & $\begin{array}{l}-0.091 \\
(0.063)\end{array}$ & $\begin{array}{l}0.190^{* *} \\
(0.074)\end{array}$ & $\begin{array}{l}-0.003 \\
(0.085)\end{array}$ & $\begin{array}{l}-0.112 \\
(0.079)\end{array}$ & $\begin{array}{c}0.199^{* * *} \\
(0.067)\end{array}$ & $\begin{array}{l}-0.108^{*} \\
(0.063)\end{array}$ \\
\hline \multirow[t]{2}{*}{ Unexplained } & $\begin{array}{c}0.500^{* * *} \\
(0.099) \\
\end{array}$ & $\begin{array}{c}0.820^{* * *} \\
(0.104) \\
\end{array}$ & $\begin{array}{c}0.120 \\
(0.074) \\
\end{array}$ & $\begin{array}{c}0.735^{* * *} \\
(0.102) \\
\end{array}$ & $\begin{array}{c}0.169 \\
(0.104) \\
\end{array}$ & $\begin{array}{c}-0.682^{* * *} \\
(0.105) \\
\end{array}$ & $\begin{array}{l}0.308^{* *} \\
(0.125) \\
\end{array}$ & $\begin{array}{c}0.643^{* * *} \\
(0.107) \\
\end{array}$ & $\begin{array}{c}0.706^{* * *} \\
(0.151) \\
\end{array}$ & $\begin{array}{c}0.869^{* * *} \\
(0.115) \\
\end{array}$ & $\begin{array}{c}0.857^{* * *} \\
(0.109) \\
\end{array}$ \\
\hline & \multicolumn{11}{|c|}{ RIF B-O decomposition for 50th Percentile } \\
\hline \multirow{2}{*}{$\begin{array}{l}\text { I. Differential } \\
\text { Benchmark (Finland) }\end{array}$} & & & & & & & & & & & \\
\hline & $\begin{array}{c}6.038^{* * *} \\
(0.045)\end{array}$ & $\begin{array}{c}6.038^{* * *} \\
(0.045)\end{array}$ & $\begin{array}{c}6.038^{* * *} \\
(0.045)\end{array}$ & $\begin{array}{c}6.038^{* * *} \\
(0.045)\end{array}$ & $\begin{array}{c}6.038^{* * *} \\
(0.045)\end{array}$ & $\begin{array}{c}6.038^{* * *} \\
(0.045)\end{array}$ & $\begin{array}{c}6.038^{* * *} \\
(0.045)\end{array}$ & $\begin{array}{c}6.038^{* * *} \\
(0.045)\end{array}$ & $\begin{array}{c}6.038^{* * *} \\
(0.045)\end{array}$ & $\begin{array}{c}6.038^{* * *} \\
(0.045)\end{array}$ & $\begin{array}{c}6.038^{* * *} \\
(0.045)\end{array}$ \\
\hline Compared country & $\begin{array}{c}5.704^{* * *} \\
(0.032)\end{array}$ & $\begin{array}{c}4.840^{* * *} \\
(0.041)\end{array}$ & $\begin{array}{c}5.735^{* * *} \\
(0.060)\end{array}$ & $\begin{array}{c}4.981^{* * *} \\
(0.067)\end{array}$ & $\begin{array}{c}6.377^{* * *} \\
(0.081)\end{array}$ & $\begin{array}{c}6.422^{* * *} \\
(0.034)\end{array}$ & $\begin{array}{c}5.572^{* * *} \\
(0.057)\end{array}$ & $\begin{array}{c}4.928^{* * *} \\
(0.052)\end{array}$ & $\begin{array}{c}6.333^{* * *} \\
(0.074)\end{array}$ & $\begin{array}{c}5.001^{* * *} \\
(0.067)\end{array}$ & $\begin{array}{c}5.726^{* * *} \\
(0.095)\end{array}$ \\
\hline Difference (raw) & $\begin{array}{c}0.335^{* * *} \\
(0.055)\end{array}$ & $\begin{array}{c}1.198^{* * *} \\
(0.061)\end{array}$ & $\begin{array}{c}0.304^{* * *} \\
(0.075)\end{array}$ & $\begin{array}{c}1.058^{* * *} \\
(0.081)\end{array}$ & $\begin{array}{c}-0.338^{* * *} \\
(0.092)\end{array}$ & $\begin{array}{c}-0.383^{* * *} \\
(0.056)\end{array}$ & $\begin{array}{c}0.467^{* * *} \\
(0.072)\end{array}$ & $\begin{array}{c}1.110^{* * *} \\
(0.069)\end{array}$ & $\begin{array}{c}-0.294^{* * *} \\
(0.086)\end{array}$ & $\begin{array}{c}1.037^{* * *} \\
(0.081)\end{array}$ & $\begin{array}{c}0.313^{* * *} \\
(0.105)\end{array}$ \\
\hline Difference (\%) & $5.7 \%$ & $22.0 \%$ & $5.1 \%$ & $19.2 \%$ & $-5.5 \%$ & $-6.2 \%$ & $8.0 \%$ & $20.2 \%$ & $-4.8 \%$ & $18.8 \%$ & $5.3 \%$ \\
\hline \multicolumn{12}{|l|}{ II. Decomposition } \\
\hline Explained & $\begin{array}{c}0.116^{* *} \\
(0.051)\end{array}$ & $\begin{array}{c}0.220^{* * *} \\
(0.065)\end{array}$ & $\begin{array}{c}-0.320^{* * *} \\
(0.049)\end{array}$ & $\begin{array}{c}0.128^{* * *} \\
(0.048)\end{array}$ & $\begin{array}{c}-0.092^{*} \\
(0.051)\end{array}$ & $\begin{array}{c}-0.111^{* *} \\
(0.053)\end{array}$ & $\begin{array}{c}0.247^{* * *} \\
(0.061)\end{array}$ & $\begin{array}{c}-0.316^{* * *} \\
(0.073)\end{array}$ & $\begin{array}{c}-0.117^{*} \\
(0.068)\end{array}$ & $\begin{array}{l}0.136^{* *} \\
(0.060)\end{array}$ & $\begin{array}{c}-0.171^{* * *} \\
(0.051)\end{array}$ \\
\hline \multirow[t]{2}{*}{ Unexplained } & $\begin{array}{c}0.219^{* * *} \\
(0.076)\end{array}$ & $\begin{array}{c}0.978^{* * *} \\
(0.090)\end{array}$ & $\begin{array}{c}0.624^{* * *} \\
(0.088) \\
\end{array}$ & $\begin{array}{c}0.930^{* * *} \\
(0.094) \\
\end{array}$ & $\begin{array}{c}-0.246^{* *} \\
(0.105) \\
\end{array}$ & $\begin{array}{c}-0.272^{* * *} \\
(0.077) \\
\end{array}$ & $\begin{array}{l}0.219^{* *} \\
(0.095) \\
\end{array}$ & $\begin{array}{c}1.426^{* * *} \\
(0.098) \\
\end{array}$ & $\begin{array}{l}-0.177 \\
(0.109)\end{array}$ & $\begin{array}{c}0.901^{* * *} \\
(0.101)\end{array}$ & $\begin{array}{c}0.484^{* * *} \\
(0.116) \\
\end{array}$ \\
\hline & \multicolumn{11}{|c|}{ RIF B-O decomposition for 90th Percentile } \\
\hline \multicolumn{12}{|l|}{ I. Differential } \\
\hline Benchmark (Finland) & $\begin{array}{c}7.484^{* * *} \\
(0.039)\end{array}$ & $\begin{array}{c}7.484^{* * *} \\
(0.039)\end{array}$ & $\begin{array}{c}7.484^{* * *} \\
(0.039)\end{array}$ & $\begin{array}{c}7.484^{* * *} \\
(0.039)\end{array}$ & $\begin{array}{c}7.484^{* * *} \\
(0.039)\end{array}$ & $\begin{array}{c}7.484^{* * *} \\
(0.039)\end{array}$ & $\begin{array}{c}7.484^{* * *} \\
(0.039)\end{array}$ & $\begin{array}{c}7.484^{* * *} \\
(0.039)\end{array}$ & $\begin{array}{c}7.484^{* * *} \\
(0.039)\end{array}$ & $\begin{array}{c}7.484^{* * *} \\
(0.039)\end{array}$ & $\begin{array}{c}7.484^{* * *} \\
(0.039)\end{array}$ \\
\hline Compared country & $\begin{array}{c}7.509^{* * *} \\
(0.043)\end{array}$ & $\begin{array}{c}6.825^{* * *} \\
(0.061)\end{array}$ & $\begin{array}{c}7.600^{* * *} \\
(0.062)\end{array}$ & $\begin{array}{c}7.176^{* * *} \\
(0.102)\end{array}$ & $\begin{array}{c}7.857^{* * *} \\
(0.055)\end{array}$ & $\begin{array}{c}7.549^{* * *} \\
(0.030)\end{array}$ & $\begin{array}{c}7.395^{* * *} \\
(0.080)\end{array}$ & $\begin{array}{c}7.016^{* * *} \\
(0.081)\end{array}$ & $\begin{array}{c}7.889^{* * *} \\
(0.050)\end{array}$ & $\begin{array}{c}7.054^{* * *} \\
(0.080)\end{array}$ & $\begin{array}{c}7.626^{* * *} \\
(0.088)\end{array}$ \\
\hline Difference (raw) & $\begin{array}{c}-0.025 \\
(0.058)\end{array}$ & $\begin{array}{c}0.659^{* * *} \\
(0.072)\end{array}$ & $\begin{array}{l}-0.115 \\
(0.073)\end{array}$ & $\begin{array}{c}0.308^{* * *} \\
(0.109)\end{array}$ & $\begin{array}{c}-0.373^{* * *} \\
(0.068)\end{array}$ & $\begin{array}{c}-0.064 \\
(0.050)\end{array}$ & $\begin{array}{c}0.089 \\
(0.089)\end{array}$ & $\begin{array}{c}0.468^{* * *} \\
(0.090)\end{array}$ & $\begin{array}{c}-0.404^{* * *} \\
(0.064)\end{array}$ & $\begin{array}{c}0.430^{* * *} \\
(0.089)\end{array}$ & $\begin{array}{l}-0.142 \\
(0.097)\end{array}$ \\
\hline Difference $(\%)$ & $-0.3 \%$ & $9.2 \%$ & $-1.5 \%$ & $4.2 \%$ & $-4.9 \%$ & $-0.9 \%$ & $1.2 \%$ & $6.5 \%$ & $-5.3 \%$ & $5.9 \%$ & $-1.9 \%$ \\
\hline \multicolumn{12}{|l|}{ II. Decomposition } \\
\hline Explained & $\begin{array}{l}0.115^{* *} \\
(0.045)\end{array}$ & $\begin{array}{c}0.166^{* * *} \\
(0.057)\end{array}$ & $\begin{array}{c}-0.272^{* * *} \\
(0.045)\end{array}$ & $\begin{array}{c}0.109^{* * *} \\
(0.041)\end{array}$ & $\begin{array}{l}-0.067 \\
(0.045)\end{array}$ & $\begin{array}{c}-0.100^{* *} \\
(0.046)\end{array}$ & $\begin{array}{c}0.198^{* * *} \\
(0.054)\end{array}$ & $\begin{array}{c}-0.301^{* * *} \\
(0.063)\end{array}$ & $\begin{array}{l}-0.088 \\
(0.059)\end{array}$ & $\begin{array}{l}0.096^{*} \\
(0.052)\end{array}$ & $\begin{array}{c}-0.129^{* * *} \\
(0.045)\end{array}$ \\
\hline Unexplained & $\begin{array}{c}-0.140^{*} \\
(0.073)\end{array}$ & $\begin{array}{c}0.493^{* * *} \\
(0.091)\end{array}$ & $\begin{array}{l}0.156^{*} \\
(0.089)\end{array}$ & $\begin{array}{l}0.199^{*} \\
(0.116)\end{array}$ & $\begin{array}{c}-0.306^{* * *} \\
(0.082)\end{array}$ & $\begin{array}{c}0.035 \\
(0.070)\end{array}$ & $\begin{array}{l}-0.109 \\
(0.102)\end{array}$ & $\begin{array}{c}0.769^{* * *} \\
(0.112)\end{array}$ & $\begin{array}{c}-0.317^{* * * *} \\
(0.088)\end{array}$ & $\begin{array}{c}0.335^{* * *} \\
(0.102)\end{array}$ & $\begin{array}{l}-0.013 \\
(0.108)\end{array}$ \\
\hline
\end{tabular}

Note: In addition to basic socio-economic characteristics, variables capturing experience with finance (i.e. having budget, having savings products, holding risky financial assets, and engaging in financial planning) are considered in the underlying regressions. Robust standard errors presented in parentheses. ${ }^{*} p<0.10,{ }^{* *} p<0.05,{ }^{* * *} p<0.01$.

Source: OECD/INFE international survey of adult financial literacy competencies 


\section{B.3 Unexplained gaps and the role of institutions}

The results shown in figures B.1 and B.2 suggest that at the 10th percentile of the financial literacy score distribution, experience with financial products does not matter much as the solid and dashed lines capturing the baseline and experience specifications are not far away from each other, without slopes changing either. In other words, the financial literacy of individuals in this part of the distribution is likely obtained by the basic channel (i.e. mainly education, age, working status). On the other hand, at the 90th percentile of the financial literacy score distributions, experience with financial products matters more in countries with less developed institutions, being further away from the benchmark, Finland. In these countries, the gap in financial literacy in the upper part of the distribution is strongly reduced if individuals are compared within experience groups. In other words, this means that in these countries (i.e. Brazil, Croatia, Hungary, Jordan, and Russia) the financial literacy of this group of people is closer to their counterparts in countries with higher average financial literacy due to their own experience. Table B.4 shows the results of the standardized ranking of institutions as shown in subsection 4.4 but based on decomposition estimates including experience. Note that as the unexplained parts are smaller once experience is included, the correlation to institutions also has a tendency to be smaller. 
Figure B.1: Estimated coefficient effects from the mean B-O decomposition versus selected macroeconomic indicators (robustness check)

(a) Internet

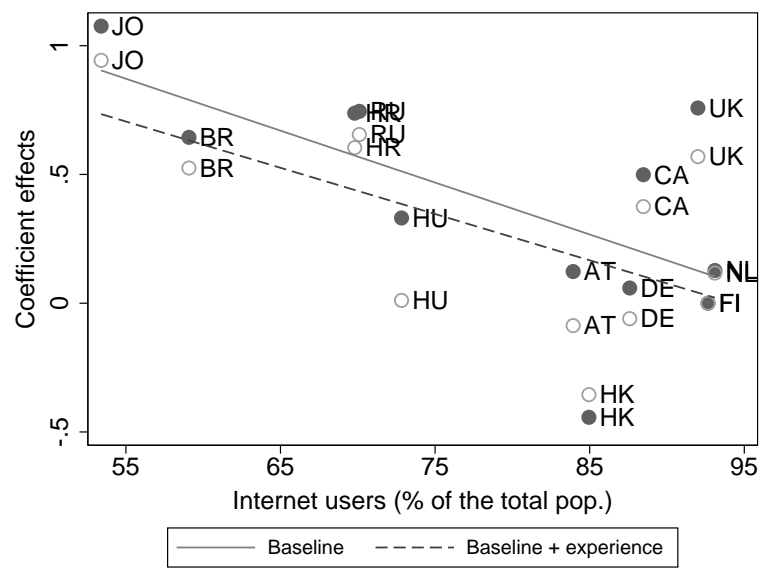

(c) Math in PISA

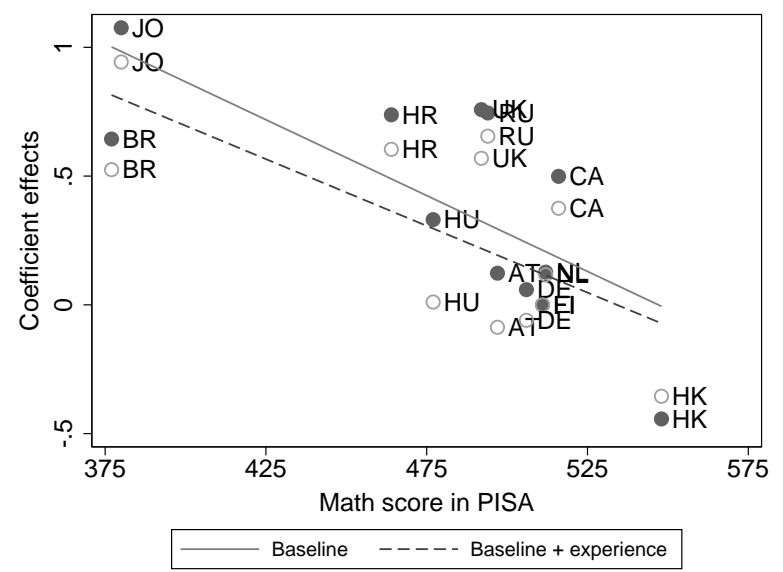

(b) Life expectancy

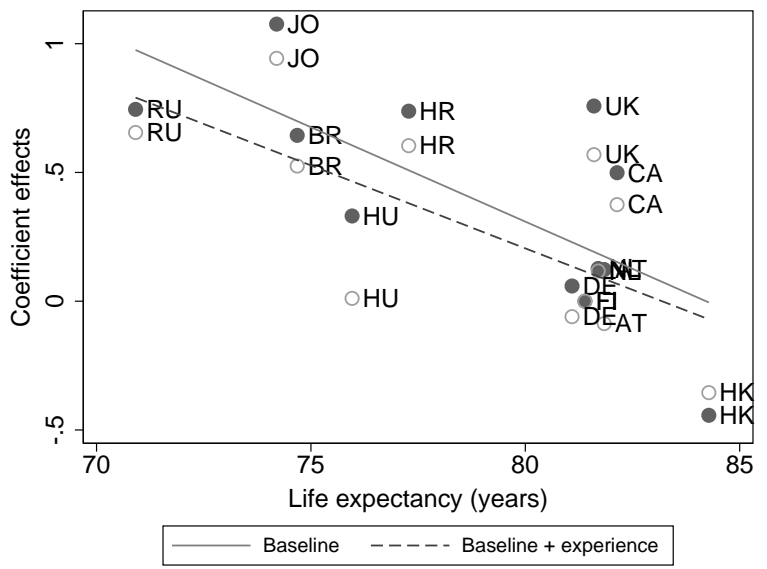

(d) Welfare state

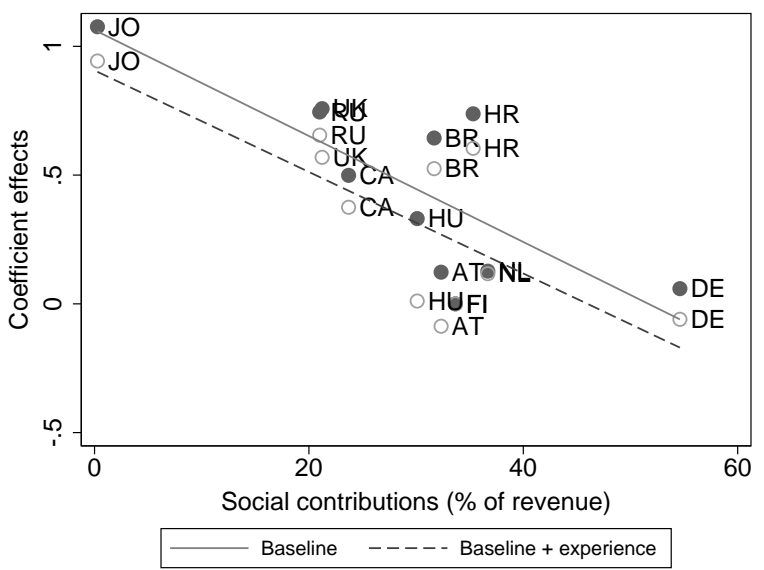

Note: Austria (AT), Brazil (BR), Canada (CA), Croatia (HR), Finland (FI), Germany (DE), Hong Kong (HK), Hungary (HU), Jordan (JO), The Netherlands (NL), Russia (RU), the United Kingdom (UK).

Source: OECD/INFE international survey of adult financial literacy competencies, World Bank data 
Figure B.2: Estimated coefficient effects from the RIF B-O quantile decomposition versus selected macroeconomic indicators (robustness check)

(a) Internet
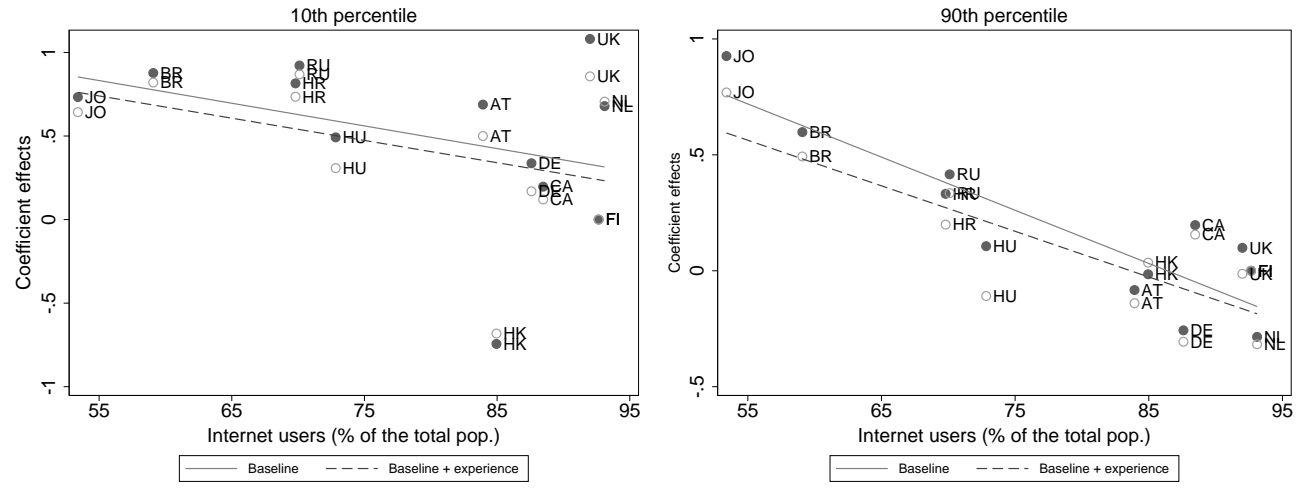

(b) Life expectancy
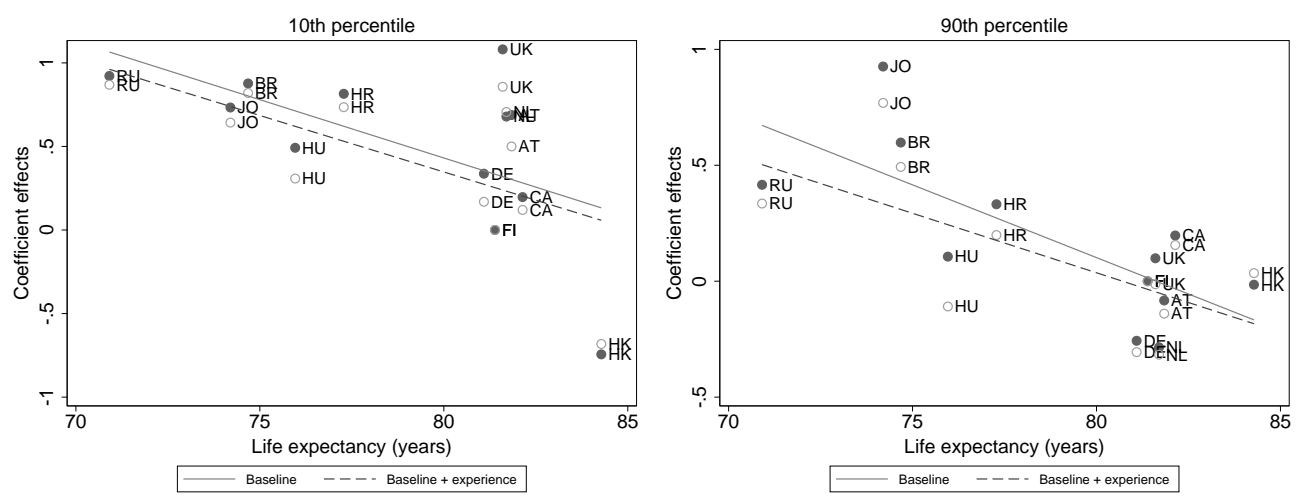

(c) Math in PISA
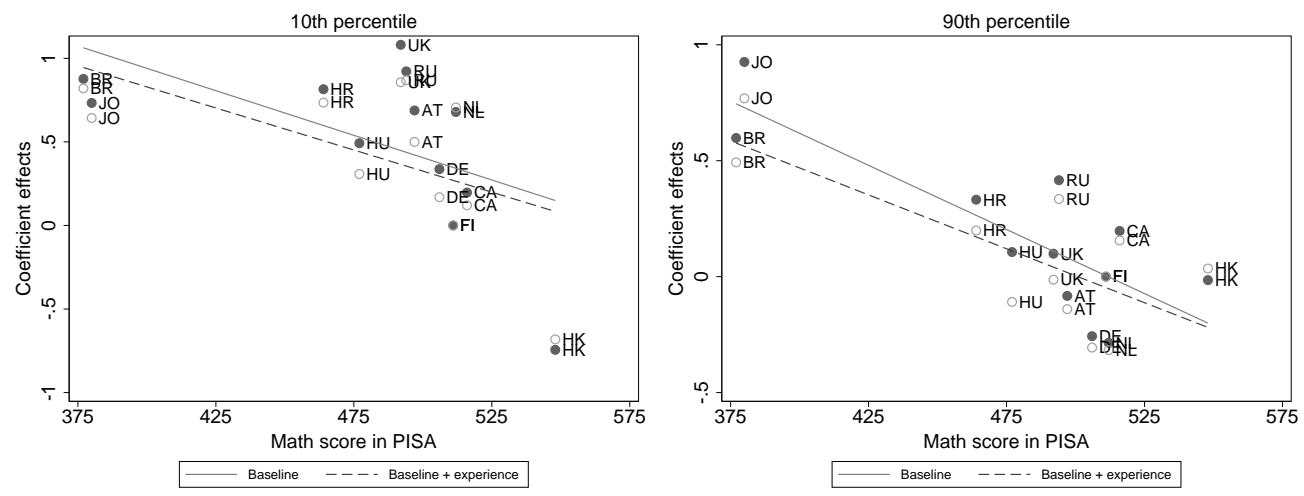

Note: Austria (AT), Brazil (BR), Canada (CA), Croatia (HR), Finland (FI), Germany (DE), Hong Kong (HK), Hungary (HU), Jordan (JO), The Netherlands (NL), Russia (RU), the United Kingdom (UK).

Source: OECD/INFE international survey of adult financial literacy competencies, World Bank data 
Table B.4: Which institutions matter the most? (robustness check)

\begin{tabular}{|c|c|c|c|c|c|c|}
\hline \multirow[b]{2}{*}{ Indicator } & \multicolumn{2}{|l|}{ Mean } & \multicolumn{2}{|c|}{ 10th percentile } & \multicolumn{2}{|c|}{ 90th percentile } \\
\hline & Standardized effect & Rank & Standardized effect & Rank & Standardized effect & Rank \\
\hline GDP per capita & $-0.253^{* *}$ & 5 & $-0.217^{*}$ & 5 & $-0.237^{* *}$ & 5 \\
\hline Gross enrolment ratio & $-0.242^{* * *}$ & 6 & $-0.243^{*}$ & 4 & $-0.189^{*}$ & 6 \\
\hline Internet users & $-0.264^{*}$ & 4 & -0.196 & 6 & $-0.289^{* * *}$ & 2 \\
\hline Life expectancy & $-0.452^{* *}$ & 1 & $-0.474^{* *}$ & 1 & $-0.360^{* *}$ & 1 \\
\hline Math score in PISA & $-0.265^{* * *}$ & 3 & $-0.258^{*}$ & 3 & $-0.238^{* * *}$ & 4 \\
\hline Social contributions rate & $-0.288^{* * *}$ & 2 & $-0.123^{*}$ & 7 & $-0.279^{* * *}$ & 3 \\
\hline Stock market capitalization & $-0.184^{* * *}$ & 7 & $-0.326^{* * *}$ & 2 & -0.036 & 7 \\
\hline
\end{tabular}

Note: Country-level regressions of the unexplained parts of the gap (coefficient effects) estimated from the mean and quantile decomposition analysis on a set of aggregate indicators (one by one) which have been standardized (i.e. values demeaned and divided by their standard deviations). ${ }^{*} p<0.10,{ }^{* *} p<0.05,{ }^{* * *}$ $p<0.01$.

Source: OECD/INFE international survey of adult financial literacy competencies; World Bank data 


\section{Index of Working Papers:}

\begin{tabular}{llrl}
\hline $\begin{array}{l}\text { March 5, } \\
2015\end{array}$ & $\begin{array}{l}\text { Jonas Dovern, } \\
\text { Martin Feldkircher, } \\
\text { Florian Huber }\end{array}$ & $200 \begin{array}{l}\text { Does Joint Modelling of the World Economy } \\
\text { Pay Off? Evaluating Global Forecasts from a } \\
\text { Bayesian GVAR }\end{array}$ \\
\hline $\begin{array}{l}\text { May 19, } \\
2015\end{array}$ & Markus Knell & 201 & $\begin{array}{l}\text { The Return on Social Security with } \\
\text { Increasing Longevity }\end{array}$ \\
\hline $\begin{array}{l}\text { June 15, } \\
2015\end{array}$ & Anil Ari & 202 & Sovereign Risk and Bank Risk-Taking \\
\hline $\begin{array}{l}\text { June 15, } \\
2015\end{array}$ & Matteo Crosignani & 203 & $\begin{array}{l}\text { Why Are Banks Not Recapitalized During } \\
\text { Crises? }\end{array}$ \\
\hline $\begin{array}{l}\text { February 19, } \\
2016\end{array}$ & Burkhard Raunig & 204 & Background Indicators \\
\hline
\end{tabular}

\begin{tabular}{|c|c|c|c|}
\hline $\begin{array}{l}\text { February 22, } \\
2016\end{array}$ & $\begin{array}{l}\text { Jesús Crespo } \\
\text { Cuaresma, } \\
\text { Gernot Doppelhofer, } \\
\text { Martin Feldkircher, } \\
\text { Florian Huber }\end{array}$ & 205 & US Monetary Policy in a Globalized World \\
\hline $\begin{array}{l}\text { March 4, } \\
2016\end{array}$ & $\begin{array}{l}\text { Helmut Elsinger, } \\
\text { Philipp Schmidt- } \\
\text { Dengler, } \\
\text { Christine Zulehner }\end{array}$ & 206 & Competition in Treasury Auctions \\
\hline
\end{tabular}

\begin{tabular}{llrl}
\hline $\begin{array}{l}\text { May 14, } \\
2016\end{array}$ & $\begin{array}{l}\text { Apostolos } \\
\text { Thomadakis }\end{array}$ & 207 & $\begin{array}{l}\text { Determinants of Credit Constrained Firms: } \\
\text { Evidence from Central and Eastern Europe } \\
\text { Region }\end{array}$ \\
$\begin{array}{l}\text { July 1, } \\
2016\end{array}$ & $\begin{array}{l}\text { Martin Feldkircher, } \\
\text { Florian Huber }\end{array}$ & 208 & $\begin{array}{l}\text { Unconventional US Monetary Policy: New } \\
\text { Tools Same Channels? }\end{array}$ \\
\hline $\begin{array}{l}\text { November 24, } \\
2016\end{array}$ & François de Soyres & 209 & $\begin{array}{l}\text { Value Added and Productivity Linkages } \\
\text { Across Countries }\end{array}$ \\
\hline $\begin{array}{l}\text { November 25, } \\
2016\end{array}$ & Maria Coelho & 210 & $\begin{array}{l}\text { Fiscal Stimulus in a Monetary Union: } \\
\text { Evidence from Eurozone Regions }\end{array}$ \\
\hline January 9, & Markus Knell, & 211 & Inequality, Perception Biases and Trust \\
2017 & Helmut Stix & & \\
\hline
\end{tabular}




\begin{tabular}{|c|c|c|c|}
\hline $\begin{array}{l}\text { January 31, } \\
2017\end{array}$ & $\begin{array}{l}\text { Steve Ambler, } \\
\text { Fabio Rumler }\end{array}$ & 212 & $\begin{array}{l}\text { The Effectiveness of Unconventional } \\
\text { Monetary Policy Announcements in the Euro } \\
\text { Area: An Event and Econometric Study }\end{array}$ \\
\hline $\begin{array}{l}\text { May 29, } \\
2017\end{array}$ & Filippo De Marco & 213 & $\begin{array}{l}\text { Bank Lending and the European Sovereign } \\
\text { Debt Crisis }\end{array}$ \\
\hline $\begin{array}{l}\text { June 1, } \\
2017\end{array}$ & Jean-Marie Meier & 214 & $\begin{array}{l}\text { Regulatory Integration of International } \\
\text { Capital Markets }\end{array}$ \\
\hline $\begin{array}{l}\text { October 13, } \\
2017\end{array}$ & Markus Knell & 215 & Actuarial Deductions for Early Retirement \\
\hline $\begin{array}{l}\text { October 16, } \\
2017\end{array}$ & $\begin{array}{l}\text { Markus Knell, } \\
\text { Helmut Stix }\end{array}$ & 216 & Perceptions of Inequality \\
\hline $\begin{array}{l}\text { November 17, } \\
2017\end{array}$ & $\begin{array}{l}\text { Engelbert J. Dockner, } \\
\text { Manuel Mayer, } \\
\text { Josef Zechner }\end{array}$ & 217 & Sovereign Bond Risk Premiums \\
\hline $\begin{array}{l}\text { December 1, } \\
2017\end{array}$ & $\begin{array}{l}\text { Stefan Niemann, } \\
\text { Paul Pichler }\end{array}$ & 218 & $\begin{array}{l}\text { Optimal fiscal policy and sovereign debt } \\
\text { crises }\end{array}$ \\
\hline $\begin{array}{l}\text { January 17, } \\
2018\end{array}$ & Burkhard Raunig & 219 & $\begin{array}{l}\text { Economic Policy Uncertainty and the } \\
\text { Volatility of Sovereign CDS Spreads }\end{array}$ \\
\hline $\begin{array}{l}\text { February 21, } \\
2018\end{array}$ & $\begin{array}{l}\text { Andrej Cupak, } \\
\text { Pirmin Fessler, } \\
\text { Maria Silgoner, } \\
\text { Elisabeth Ulbrich }\end{array}$ & 220 & $\begin{array}{l}\text { Exploring differences in financial literacy } \\
\text { across countries: the role of individual } \\
\text { characteristics and institutions }\end{array}$ \\
\hline
\end{tabular}

